\title{
DAYA SAING EKSPOR TEKSTIL DAN PRODUK TEKSTIL INDONESIA DAN VIETNAM KE AMERIKA SERIKAT DAN REPUBLIK RAKYAT TIONGKOK
}

\section{Export Competitiveness of Textiles and Textile Products of Indonesia and Vietnam to the United States of America and People's Republic of China}

\author{
Ragimun \\ Pusat Kebijakan Regional dan Bilateral, Badan Kebijakan Fiskal, Kementerian Keuangan-RI \\ JI. Dr. Wahidin No. 1, Jakarta Pusat 10710, Indonesia \\ Email: ragimun@gmail.com
}

Naskah diterima: 06/04/2017; Naskah direvisi: 25/05/2017; Disetujui diterbitkan: 12/11/2018

Dipublikasikan online: 31/12/2018

\begin{abstract}
Abstrak
Tekstil dan Produk Tekstil (TPT) adalah produk ekspor utama Indonesia dan Vietnam. Penelitian ini bertujuan menganalisis daya saing ekspor TPT Indonesia dan Vietnam di pasar AS dan RRT. Metode yang digunakan adalah Constant Market Share Analysis (CMSA), Revealed Comparative Advantage (RCA), dan Model Ekonometrika (Fixed Effect Model). Hasil penelitian menunjukkan bahwa produk TPT Indonesia dan Vietnam tidak mempunyai daya saing kuat di pasar RRT, tetapi keduanya memiliki daya saing kuat di pasar AS. Pengembangan ekspor TPT Vietnam lebih terkonsentrasi di pasar RRT, sedangkan Indonesia lebih terkonsentrasi di pasar AS. TPT Indonesia mampu beradaptasi di pasar RRT dan AS, sedangkan TPT Vietnam hanya mampu beradaptasi di pasar RRT. Daya saing TPT Indonesia dan Vietnam di pasar AS dan RRT sangat dipengaruhi oleh Penanaman Modal Asing (PMA) manufaktur negara asal. Daya saing TPT Indonesia sangat dipengaruhi Produk Domestik Bruto (PDB) negara tujuan, sedangkan Vietnam sangat dipengaruhi oleh faktor nilai tukar riil, tarif, PDB negara tujuan dan PMA manufaktur Vietnam. Untuk meningkatkan daya saing ekspor TPT, Indonesia perlu memperhatikan PMA manufaktur negara asal dan PDB negara tujuan.
\end{abstract}

Kata Kunci : Tekstil dan Produk Tekstil (TPT), Daya Saing, Ekspor

\begin{abstract}
Textile and Textile Product (TPT) are the main export products of Indonesia and Vietnam. This study examined the competitiveness of Indonesian and Vietnamese TPT in the US and PRC markets by using the CMSA, RCA methods and the Fixed Effect Model. The result showed TPT products from Indonesia and Vietnam do not have strong competitiveness in the PRC market, but they are highly competitive in the US market. The TPT export from Vietnam is mostly concentrated in the PRC market, while TPT from Indonesia was in the US market. Indonesian TPT is able to adapt in both PRC and US markets, while the Vietnamese TPT is only able to adapt in the PRC market. The competitiveness of Indonesian and Vietnamese TPT in the US and PRC markets is strongly influenced by the home country's FDI manufacturing. Indonesia's TPT competitiveness is strongly influenced by the GDP of the destination country, while Vietnam is strongly influenced by the factors of real exchange rates, tarrif, GDP of destination countries and Vietnam's FDI manufacturing. To improve the competitiveness of TPT export, Indonesia needs to give a great concern toward FDI manufacture and GDP of US and PRC.
\end{abstract}

Key Word: Textile and Textile Products, Competitiveness, Export

JEL Classification: L67, D41, F14 


\section{PENDAHULUAN}

Industri tekstil dan produk tekstil (TPT) Indonesia merupakan industri strategis yang mempunyai peran penting dalam perekonomian. Selama ini industri TPT berperan meningkatkan ekspor non migas, devisa negara, pendapatan masyarakat, menyerap tenaga kerja, serta menciptakan lapangan pekerjaan. Industri ini juga merupakan salah satu industri yang mendukung pemenuhan kebutuhan sandang nasional (Ridhwan, 2015).

Kedepan, industri TPT masih mempunyai prospek pasar yang menjanjikan walaupun persaingan industri TPT sangat ketat baik antar negara ASEAN maupun dunia. Beberapa negara telah menjadi pesaing utama bagi Indonesia seperti Vietnam. Saat ini Indonesia masih berada dalam urutan 10 besar dunia jajaran pemasok TPT dunia, walaupun masih berada di bawah Vietnam (Ashari, 2015). Berdasarkan pangsa pasar (market share) negara-negara pengekspor TPT dunia tahun 2014, ternyata Indonesia merupakan negara pengekspor tekstil dengan pangsa pasar $1,5 \%$ di bawah pesaing utama sesama negara ASEAN yaitu Vietnam yang mempunyai pangsa pasar sebesar 1,6\%. Demikian juga Indonesia merupakan pengekspor produk pakaian jadi terbesar dengan pangsa pasar sebesar $1,6 \%$ masih berada di bawah Vietnam dengan pangsa pasar sebesar 3,9\% (WTO, 2016).

Menurut data

Asosiasi

Pertekstilan Indonesia (API) jumlah pabrik tekstil di Indonesia meningkat sebanyak 30 unit dari 2.886 pabrik menjadi 2.916 (Kemenperin, 2015b), saat ini Indonesia merupakan salah satu pemasok TPT yang mampu memenuhi $1,8 \%$ kebutuhan dunia dengan nilai ekspor mencapai 12,46 miliar dollar USD atau setara dengan $10,7 \%$ dari total ekspor non migas. Salah satu faktor penting untuk memenangkan persaingan pasar ekspor industri TPT adalah faktor peningkatan daya saing. Berbagai program telah disiapkan oleh Pemerintah Indonesia saat ini guna memberi arah bagi pengembangan industri nasional sebagaimana termuat dalam Kebijakan Industri Nasional (KIN), Rencana Strategis (Renstra), Rencana Pembangunan Jangka Menengah (RPJM) maupun dalam Rencana Pembangunan Jangka Panjang (RPJP) (Kemendag, 2015).

Disisi lain, industri TPT Indonesia mempunyai banyak kendala dan hambatan dalam peningkatan daya 
saing tersebut. Paling tidak ada 10 masalah utama yang menjadi pemicu rendahnya daya saing TPT di Indonesia. Masalah tersebut antara lain adalah rendahnya teknologi, ketergantungan impor bahan baku, minimnya industri pendukung, rendahnya sumber daya manusia, keterbatasan modal kerja, pasokan listrik, agresif dan dinamisnya produk TPT, lemahnya kinerja ekspor, dan persoalan transportasi, serta persoalan perpajakan (Ragimun, 2010).

Permasalahan lainnya yang juga harus segera diatasi adalah tingginya jumlah mesin-mesin pada industri TPT yang diperkirakan $80 \%$ telah berusia lebih dari 20 tahun (Kemenperin, 2015a). Dengan kondisi semacam ini ternyata industri TPT Indonesia menjadi lebih boros, tidak ramah lingkungan, serta dari sisi waktu delivery sulit memenuhi kebutuhan ekspor pasar global. Permasalahan lainnya adalah ketergantungan bahan baku dan bahan penolong, antara lain adanya ketergantungan kapas impor, tidak terjaminnya kontinuitas pasokan serat sintetik, kurangnya bahan baku rayon dalam industri pemintalan, adanya ketergantungan zat pewarna dan ketergantungan impor bahan penolong berupa barang asesoris yang masih tinggi (Rosalina A., 2013).

Tantangan berat TPT Indonesia adalah mampu meningkatkan daya saing. Oleh karena itu, salah satu program industri dalam negeri diantaranya adalah mampu memproduksi mesin-mesin pertekstilan yang lebih murah sehingga dalam jangka panjang tidak perlu lagi mengimpor mesin-mesin untuk industri TPT. Pembuatan mesin-mesin pertekstilan tersebut tentu saja harus didukung dengan industri komponen dan industri motor penggerak serta sektor-sektor industri ringan lainnya (Imawan R, 2002).

Permasalahan dalam meningkatkan daya saing TPT Indonesia dapat dikelompokkan menjadi dua, yaitu (1) permasalahan internal antara lain permasalahan bahan baku dan bahan penolong, teknologi, sumber daya manusia dan modal kerja, serta energi serta (2) permasalahan eksternal antara lain transportasi, pelabuhan, perpajakan, ekonomi makro baik domestik maupun global (Kurniadi, 2017).

Selain itu, ada juga permasalahan yang berkaitan dengan permintaan TPT beberapa negara besar seperti Amerika 
Serikat dan RRT, termasuk pesatnya perkembangan beberapa negara pesaing seperti Vietnam, Kamboja, Bangladesh dan lain-lain. Oleh karena itu penulis tertarik untuk menganalisis daya saing ekspor TPT Indonesia dan Vietnam ke pasar ekspor AS dan RRT. Dua negara tujuan ekspor tersebut menjadi menarik menjadi obyek penelitian karena permintaan TPT dunia negara ini sangat tinggi. Disamping itu, peluang untuk masuk ke kedua pasar ekspor negara tersebut juga sangat besar.

Lotfi \& Karim (2016) telah melakukan penelitian mengenai determinan daya saing ekspor untuk negara Maroko berdasarkan nilai tukar, tarif, permintaan luar negeri, dan investasi asing atau Foreign Direct Investment (FDI). Lotfi \& Karim melakukan regresi terhadap berbagai subsektor diantaranya pertanian, pertambangan, dan sektor industri. Hasil penelitian menemukan bahwa kinerja ekspor, terkait tarif dan investasi asing ternyata tidak selalu memiliki elastisitas yang tidak sesuai dengan teori ekonomi. Namun, hasil regresi tersebut masih sesuai dengan teori ekonomi khusus untuk subsektor industri tekstil.
Penelitian ini menggunakan persamaan ekonometrika yang mengadopsi model Lotfi \& Karim (2016), bahwa daya saing (RCA) dipengaruhi beberapa faktor antara lain nilai tukar negara tujuan ekspor, tarif, Produk Domestik Bruto (PDB) negara tujuan ekspor dan FDI.

\section{METODE}

Penelitian ini adalah menggunakan pendekatan deskriptif eksploratif untuk menggambarkan daya saing TPT Indonesia dengan menggunakan Revealed Comparative Advantage (RCA), Constant Market Share Analysis (CMSA), dan Model Ekonometrika (Fixed Effect Model).

Untuk menganalisis daya saing TPT Indonesia dan Vietnam digunakan pendekatan RCA yang menganalisis daya saing secara komparatif yaitu dengan membandingkan daya saing TPT Indonesia dengan Vietnam. Sedangkan, pendekatan CMSA lebih menekankan analisis daya saing secara kompetitif dengan melihat kemampuan daya saing TPT untuk memformulasikan strategi pada posisi yang menguntungkan bagi Indonesia. Rumus RCA adalah sebagai berikut: (Tambunan, 2001) 
$\mathrm{RCA}=\frac{(\text { Xia }) /(\text { totalXa })}{(\text { Xiw }) /(\text { totalXw) }}$

dengan:

$X=$ ekspor atau nilai ekspor ;

$\mathrm{i}=$ jenis komoditi;

$\mathrm{a}=$ negara asal;

$\mathrm{w}=$ dunia $($ world $)$.

Bila RCA $<1$ atau mendekati 0 , maka dapat dikatakan daya saing komoditi lemah, dan bila RCA > 1 maka daya saing dapat dikatakan kuat. Semakin tinggi RCA suatu komoditi maka semakin tangguh daya saingnya. Sebenarnya RCA merupakan konsep yang lebih umum digunakan untuk mengukur comparative advantage, tetapi secara tidak langsung juga dapat menggambarkan daya saing (Erkan \& Saricoban, 2014).

Alat analisis berikutnya adalah Constant Market Share Analysis (CMSA) yang pertama kali diterapkan pada studi perdagangan internasional oleh Tyszynski (1951). Menurut Basri \& Munandar (2010) dan Permatasari (2014), pertumbuhan ekspor suatu negara bisa meningkat lebih cepat atau lebih lambat dibandingkan dengan pertumbuhan ekspor dunia. Hal ini mempunyai tiga sumber atau efek yaitu:
1) Efek komposisi komoditas, dimana ekspor dapat terkonsentrasi pada komoditas-komoditas yang permintaannya relatif elastis atau inelastis terhadap pendapatan.

2) Efek distribusi pasar, dimana ekspor dapat terarah ke pasar-pasar yang berkembang lebih pesat atau lebih lambat dibandingkan dengan ratarata dunia.

3) Efek daya saing, dimana ekspor dapat lebih atau kurang bersaing dengan negara-negara pengekspor lain, baik karena pertumbuhan produktivitasnya lebih tinggi atau lebih rendah dan dapat terjadi karena under atau overvaluation mata uang domestik.

Menurut Balassa (1989), CMSA dilakukan untuk penentuan tiga karakteristik produk yaitu: daya saing produk, responsibilitas produk terhadap permintaan pasar dan kecenderungan akses pasar bagi produk yang berdaya saing, misalnya seperti di pasar AS atau di pasar RRT dengan melihat pangsa pasar. Model CMSA digunakan karena ada situasi yang memungkinan pergerakan laju pertumbuhan ekspor suatu negara pada suatu periode tidak mampu 
mengikuti pergerakan laju pertumbuhan rata-rata ekspor dunia. Hal ini dapat terjadi karena negara pengekspor menfokuskan pada komoditas tertentu yang laju pertumbuhan produk tersebut relatif lambat.

Perhitungan CMSA digunakan untuk mengetahui keunggulan kompetitif atau daya saing ekspor di pasar dunia dari suatu negara produsen terhadap negara-negara pesaing. Model ini menunjukkan perhitungan yang mempunyai aspek tidak hanya melihat daya saing semata tetapi juga dapat melihat produk-produk utama dari produk tersebut terhadap perubahan permintaan dunia atau negara-negara mitra dagangnya (Balassa dalam Nurlatifah H., 2011). Rumusan CMSA tersebut adalah sebagai berikut:

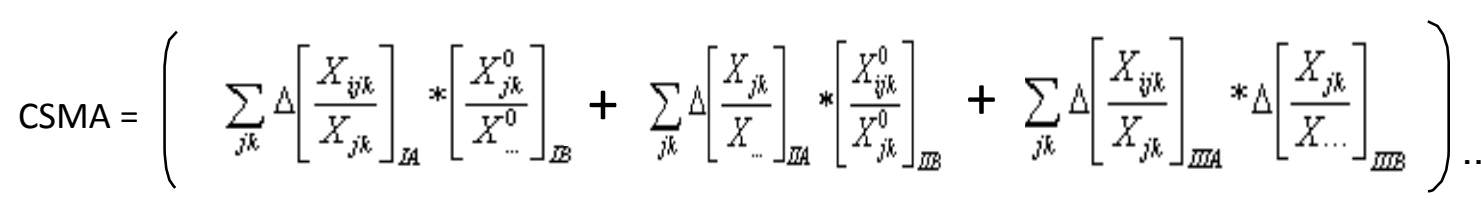

Sedangkan perhitungan CMSA yang terdiri dari 3 kriteria tersebut adalah sebagai berikut:

\section{Competitiveness Effect}

merupakan keuntungan atau kerugian dalam pangsa pasar yang menunjukkan daya saing produk. Penghitungannya adalah mengukur perubahan share negara eksportir di pasar tujuan impor (IA) dikalikan dengan $\mathrm{j}$ share dari impor negara mitra dagang atau negara tujuan ekspor di pasar dunia (IB). Atau dapat dikatakan bahwa CE diperoleh dengan menghitung dari perubahan dalam negara-negara pengekspor dibagi impor pasar tujuan (IA), dikalikan dengan pangsa awal impor negara- negara mitra dalam perdagangan dunia (IB).

$$
\sum_{j k} \Delta\left[\frac{X_{i k}}{X_{j k}}\right]_{Z A} *\left[\frac{X_{j k}^{0}}{X_{\cdots}^{0}}\right]_{\mathbb{B B}}
$$

$X_{\mathrm{ijk}}$ : ekspor untuk komoditi j dari negara asal $\mathrm{k}$ (misalnya Indonesia) ke negara tujuan $\mathrm{i}$

i : ekspor negara tujuan

j : jenis komoditas

$\mathrm{k}$ : negara asal

$X_{\mathrm{jk}}$ : ekspor komoditi j dari negara asal k (misalnya Indonesia)

$X_{j k}^{0}$ : ekspor komoditi j dari negara asal k (Indonesia) ke negara tujuan pada periode awal (0) $X^{0}$ : ekspor dunia periode awal (0) 
Bila hasil CE positif berarti semakin tinggi daya saing produk tersebut di negara tujuan ekspor, sebaliknya bila hasil CE negatif berarti semakin lemah daya saing produk tersebut di negara tujuan ekspor dan bila hasil CE nol berarti tidak mempunyai daya saing produk tersebut di negara tujuan ekspor.

\section{Initial Specialization (IS), yaitu} indikator yang menunjukkan bahwa produk-produk tertentu memiliki ciri khas di suatu pasar tertentu yang dapat dikembangkan.

$$
\sum_{j k} \Delta\left[\frac{X_{j k}}{X_{\ldots}}\right]_{\mathbb{Z A}} *\left[\frac{X_{j i k}^{0}}{X_{j k}^{0}}\right]_{\mathbb{Z B}}
$$

$X \ldots$ : ekspor dunia

$X_{i j k}^{0}$ : ekspor untuk komoditi j negara pesaing dari negara asal $k$ (misalnya Indonesia) ke negara tujuan i pada periode awal (0).

IS dihitung dari perubahan impor negara-negara mitra perdagangan dunia (IIA) dikalikan dengan pangsa negara asal dalam impor pasar tujuan (IIB). Bila hasil IS positif berarti semakin memiliki kekuatan untuk memasuki pasar di negara tujuan, sebaliknya bila hasil IS negatif berarti semakin tidak memiliki kekuatan untuk memasuki pasar di negara tujuan ekspor, dan bila hasil IS nol berarti tidak memiliki kekuatan untuk memasuki pasar di negara tujuan ekspor.

Adaptation (A), yaitu indikator yang menunjukkan kemampuan produk (supply of Export) dalam merespon atau menyesuaikan karena adanya perubahan permintaan dunia.

$$
\sum_{j k} \Delta\left[\frac{X_{i j k}}{X_{j k}}\right]_{\mathbb{Z M A}} * \Delta\left[\frac{X_{j k}}{X \ldots}\right]_{\mathbb{Z W}}
$$

Adaptation diperoleh dengan menghitung variasi lintas perubahan dalam mengekspor pangsa pasar negara (IIIB) dan perubahan pangsa pasar negara-negara mitra dagang pada produk tertentu di impor dunia (IIIA). Bila hasil A positif berarti menunjukkan semakin besar kemampuan produk-produk tersebut dapat beradaptasi dengan selera pasar di negara tujuan ekspor, sebaliknya bila hasil A negatif berarti menunjukkan semakin lemah kemampuan produk-produk tersebut dapat beradaptasi dengan selera pasar di negara tujuan ekspor, dan bila hasil A nol berarti menunjukkan tidak adanya kemampuan produk-produk tersebut 
dapat beradaptasi dengan selera pasar di negara tujuan ekspor.

Untuk mengetahui determinan dari daya saing ekspor industri TPT
Indonesia dan Vietnam ke AS dan RRT digunakan model ekonometri dengan rumus sebagai berikut:

$$
\boldsymbol{R C A}_{i j t}=\boldsymbol{\sigma}_{0}+\beta_{1} \boldsymbol{R E R}_{i j t}+\beta_{2} \text { Tariff }_{j \mathrm{jt}}+\beta_{3} G \boldsymbol{G} \boldsymbol{P}_{j t}+\beta_{4} \boldsymbol{F D I}_{i t}+\boldsymbol{\epsilon}_{i j t}
$$

\begin{tabular}{|c|c|c|c|}
\hline Variabel & Nama Variabel & Keterangan & Sumber \\
\hline$R C A$ & $\begin{array}{l}\text { Revealed Comparative } \\
\text { Advantage }\end{array}$ & $\begin{array}{l}\text { Perhitungan sendiri menggunakan data } \\
\text { ekspor }\end{array}$ & UNCTAD \\
\hline$R E R$ & Nilai tukar riil & $\begin{array}{l}\text { Perhitungan sendiri menggunakan data } \\
\text { nilai tukar nominal dan CPI, rata-rata } \\
\text { tahunan }\end{array}$ & World Bank \\
\hline Tariff & Tarif & Rata-rata tertimbang, produk manufaktur & World Bank \\
\hline$G D P$ & PDB negara tujuan ekspor & Harga konstan 2010 & World Bank \\
\hline FDI & Foreign Direct Investment & FDI Sektor manufaktur di negara asal & CEIC \\
\hline$i, j$ & Entitas & $\begin{array}{l}\text { Entitas negara } \mathrm{i}=\text { Indonesia dan Vietnam, } \\
\mathrm{j}=\mathrm{AS} \text { dan RRT }\end{array}$ & CEIC \\
\hline$t$ & Waktu/periode (time) & $\begin{array}{l}\text { Menjelaskan dimensi waktu / periode, } \\
\text { 1995- } 2016 \text { ( } 22 \text { tahun) }\end{array}$ & CEIC \\
\hline
\end{tabular}

Keterangan: $i$ dan $j$ bisa berbeda pada tiap kategori yang akan dijelaskan. Selain itu, $i$ dan $j$ tidak akan bolak balik (ekspor-impor), tetapi satu arah saja. Hal ini akan dijelaskan pada tiap model.

Untuk menguji determinasi daya saing TPT Indonesia dan Vietnam ke AS dan RRT digunakan 5 model yang bertujuan untuk melihat variasi hasil regresi di lihat dari kesesuaian dengan teori yang menyatakan bahwa daya saing (RCA) sebagai variabel dependen dipengaruhi oleh nilai tukar riil, tarif yang berlaku, GDP negara tujuan ekspor dan Foreign Direct investment (FDI) sebagai variabel independen.
Model 1, menggunakan keseluruhan data hubungan dagang Indonesia ke AS, Indonesia ke RRT, Vietnam ke AS dan Vietnam ke RRT ( $\mathrm{i}=$ Indonesia dan Vietnam, $\mathrm{j}=$ AS dan RRT, $\mathrm{n}=84$ )

Model 2, menggunakan keseluruhan data hubungan dagang Indonesia ke AS dan Indonesia ke RRT ( $\mathrm{i}=$ Indonesia, $\mathrm{j}=\mathrm{AS}$ dan RRT, $\mathrm{n}=42$ )

Model 3, menggunakan keseluruhan data hubungan dagang Vietnam ke AS dan Vietnam ke RRT ( $i$ = Vietnam, $j=$ AS dan RRT, $n=42$ ) 
Model 4, menggunakan keseluruhan data hubungan dagang Indonesia ke AS dan Vietnam ke AS ( $\mathrm{i}=$ Indonesia dan Vietnam, $\mathrm{j}=\mathrm{AS}, \mathrm{n}=42$ )

Model 5, menggunakan keseluruhan data hubungan dagang Indonesia ke RRT dan Vietnam ke RRT ( $\mathrm{i}=$ Indonesia dan Vietnam, $\mathrm{j}=\mathrm{RRT}, \mathrm{n}=$ 42)

Dari kelima model tersebut dapat dikelompokan menjadi tiga model utama yaitu pertama, model keseluruhan baik negara asal ekspor maupun negara pasar ekspor (model 1). Kedua, model negara asal ekspor (model 2 dan 3). Ketiga, model negara pasar ekspor (model 4 dan 5). Datadata yang digunakan adalah data sekunder yang bersumber dari UN Comtrade dan literatur yang menunjang. Data produk yang digunakan dalam analisis berdasarkan pengelompokan Harmonized System (HS digit 3).

\section{HASIL DAN PEMBAHASAN}

\section{Target TPT Indonesia dan Vietnam}

Tabel 1. Negara Eksportir dan Importir TPT Terbesar Dunia (Milyar USD)

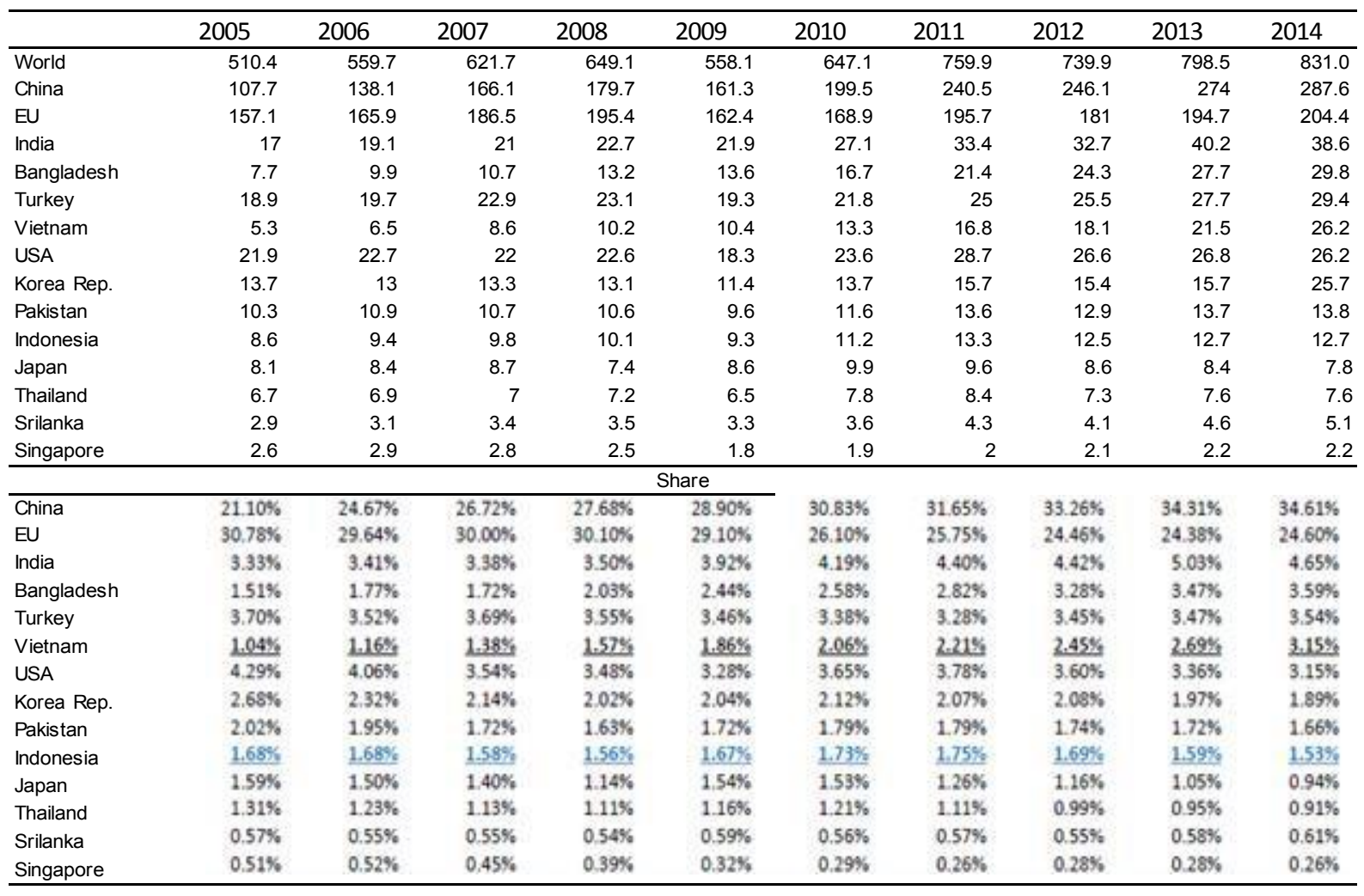

Sumber: UN Comtrade Statistics (2016) 
Peningkatan daya saing produk industri TPT Indonesia mendapat merupakan tantangan terbesar bagi ancaman serius dari negara lain. industri TPT Indonesia, terutama dalam Indonesia yang merupakan salah satu era perdagangan bebas saat ini seperti negara pengekspor produk tekstil Masyarakat Ekonomi ASEAN (MEA). terbesar ke AS mendapat tantangan Persaingan saat ini makin ketat, dan ancaman dari beberapa pesaing ditambah lagi sudah tidak diberlakukan- produsen tekstil seperti RRT, India dan nya pasar kuota yang menyebabkan Vietnam.

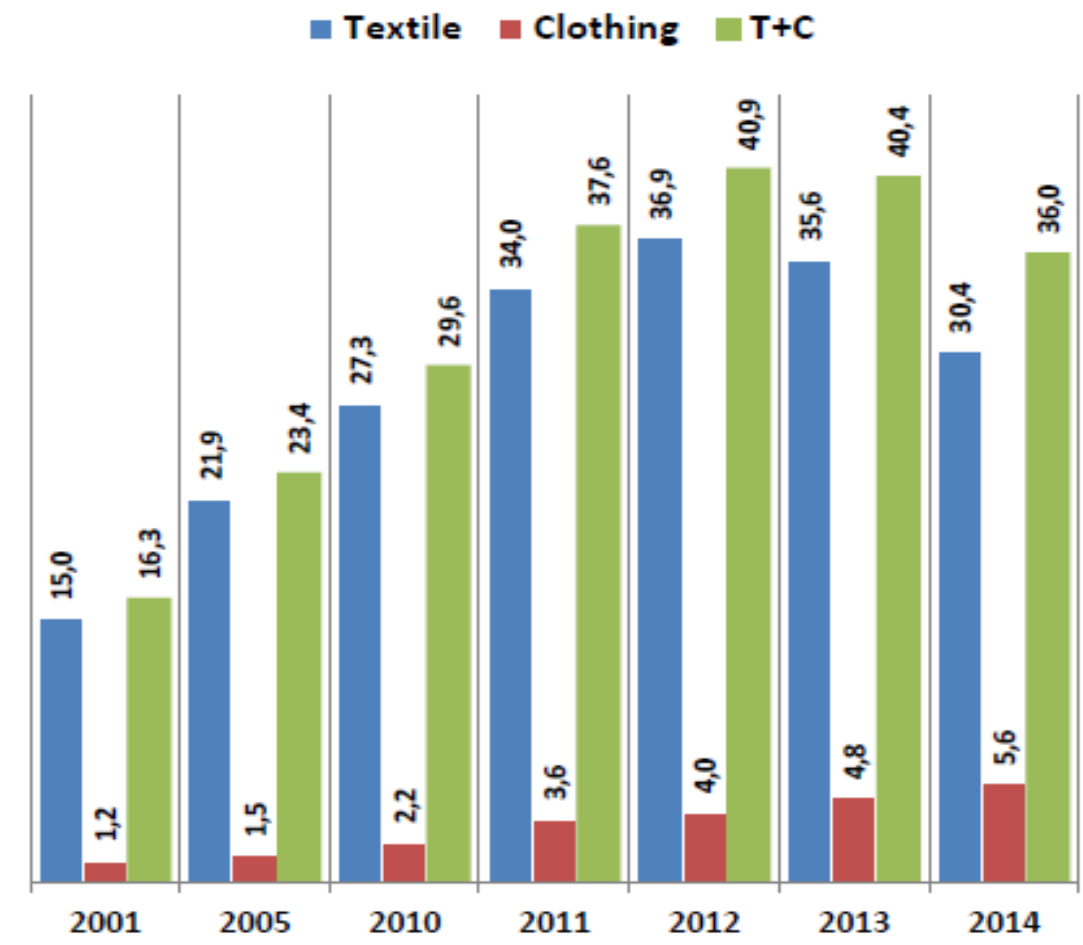

Gambar 2. Impor TPT Republik Rakyat Tiongkok (Milyar USD)

Sumber: UN Comtrade (2016)

Data tahun 2014 menunjukkan pangsa pasar RRT menguasai $34,6 \%$. Indonesia merupakan negara pengekspor ke-10 dengan 1,53\% dibawah pesaing utama sesama negara ASEAN yaitu Vietnam sebesar
3,15\%. Gambar 2 menunjukkan impor TPT RRT ternyata sangat besar. Tahun 2012 nilai impor TPT RRT mencapai 40,9 milyar USD, tahun 2014 sebesar 36 milyar USD dan didominasi impor tekstil dibanding impor pakaian jadi 
(clothing), artinya RRT lebih banyak mengimpor bahan baku berupa tekstil untuk memenuhi kebutuhan industri produk tekstilnya. Hal ini menjadi peluang besar bagi negara-negara pengekspor TPT seperti Indonesia atau Vietnam.

Gambar 3 menunjukkan bahwa pasar TPT di AS banyak dipasok dari berbagai negara produsen TPT. RRT adalah salah satu pemasok terbesar TPT ke AS. Bila dilihat dari nilainya, yang jauh melampaui negara lain seperti Indonesia dan Vietnam. Pemasok terbesar ke dua adalah Vietnam. Peningkatan ekspor Vietnam ke AS ini terjadi setelah tahun 2009.
Sejak awal tahun 2000an RRT terus mendominasi sebagai pemasok TPT ke negara tujuan AS. Pemasok utama ke Amerika dari negara ASEAN adalah Vietnam, yang dimulai sejak awal tahun 2000an. Negara ASEAN lainnya adalah Indonesia dan Cambodia. Data Januari-Maret 2015 dan 2016 ternyata ekspor TPT Indonesia ke AS mengalami penurunan khususnya pakaian jadi sedangkan Vietnam mengalami kenaikan ekspor TPT khususnya pakaian jadi. Dua negara ASEAN pemasok TPT ke Amerika Serikat yang paling menonjol adalah Indonesia dan Vietnam.

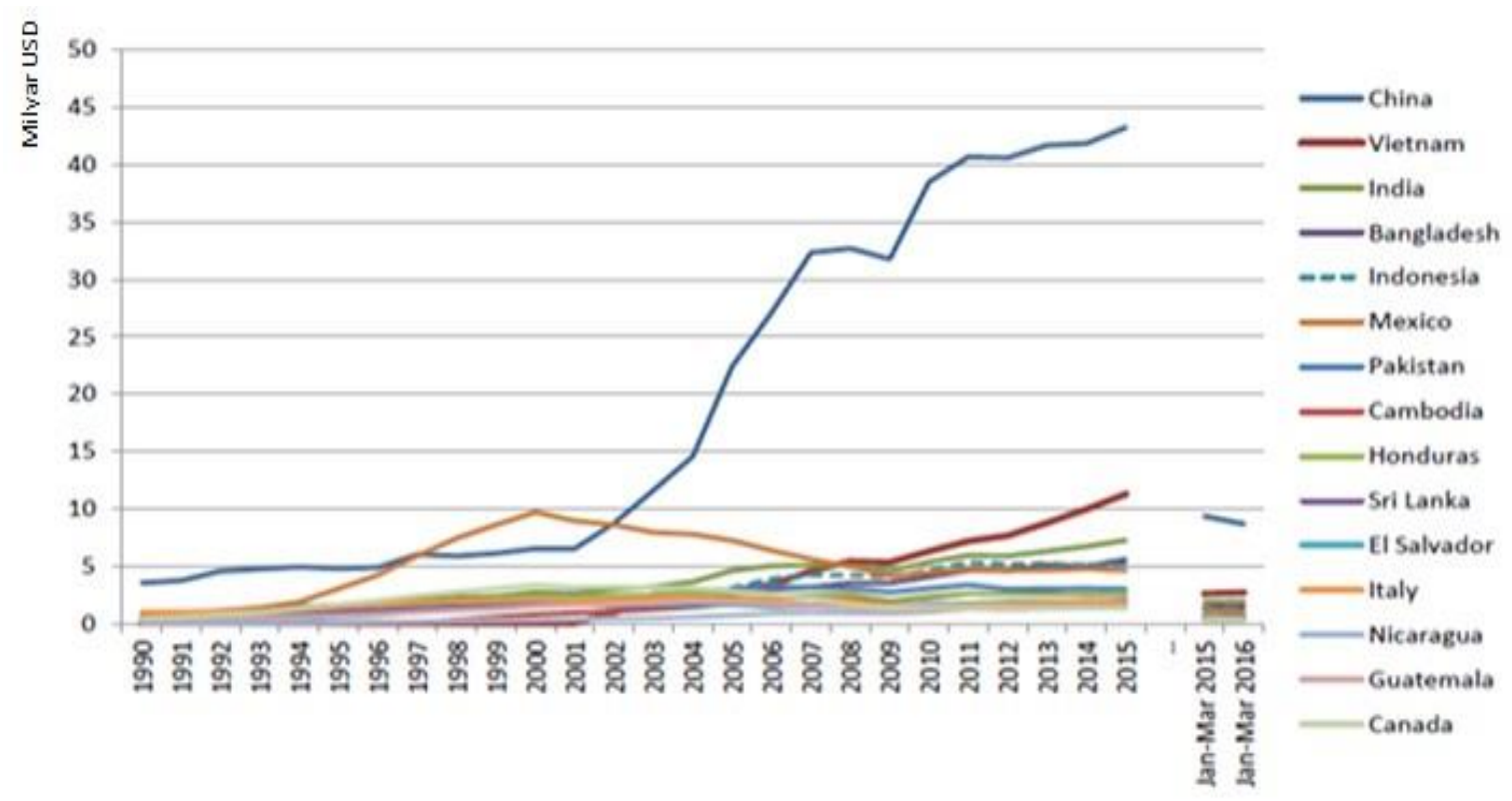

Gambar 3. Nilai Ekspor Negara Pemasok TPT ke Amerika Serikat (Milyar USD) Sumber: OTEXA (2015) 
Dari Gambar 4, walaupun nilai produk TPT Vietnam terus pemasaran TPT Indonesia ke negara meningkat. Data Januari-Maret 2015 tujuan utama seperti AS terus dan Januari-Maret 2016 terlihat meningkat namun ternyata peningkatan kenaikan nilai ekspor TPT Vietnam ke negara Vietnam jauh lebih tinggi. AS mengalami kenaikan sedangkan Terlihat pula bahwa sejak tahun 2001 Indonesia terlihat stagnan.

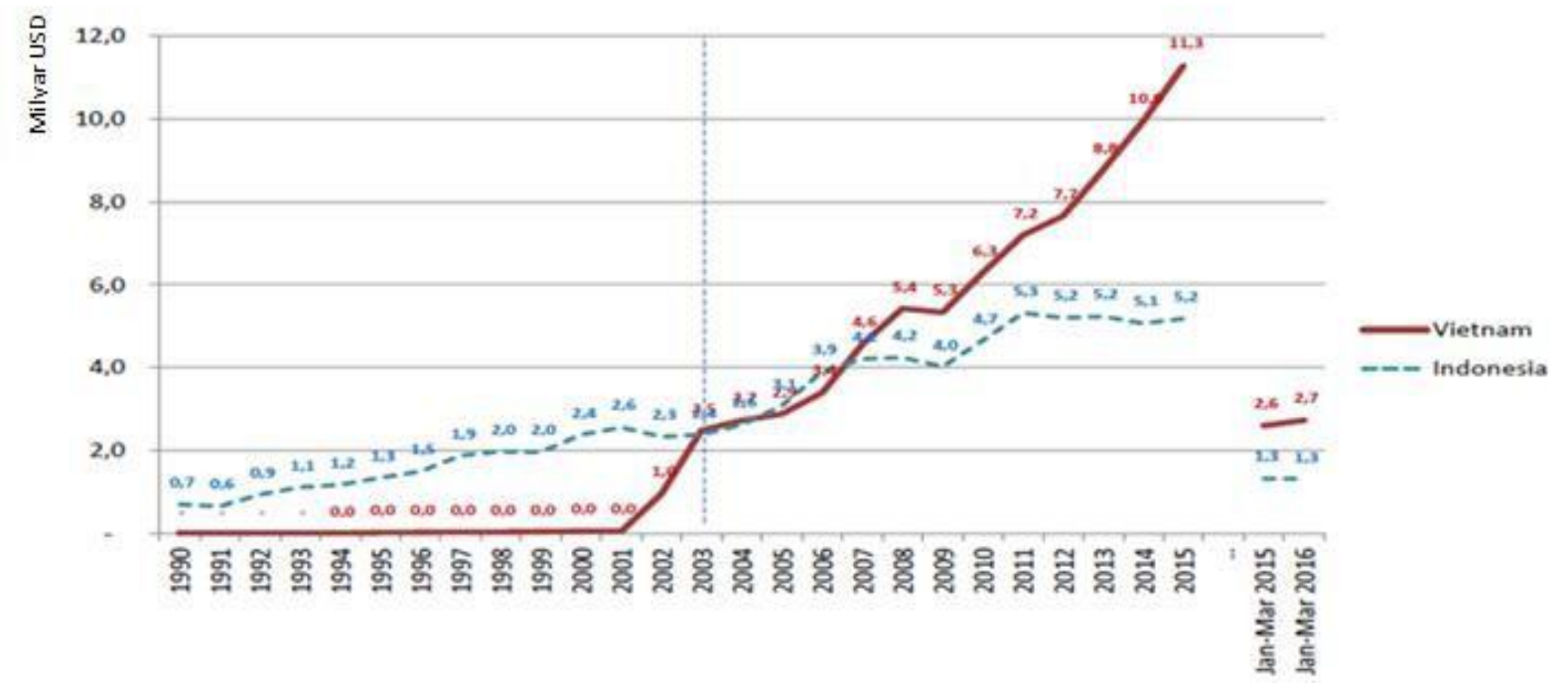

Gambar 4. Dua Negara Pemasok TPT di Pasar Amerika Serikat (Milyar USD) Sumber: OTEXA (2015)

Daya Saing, Peluang dan Potensi Ekspor TPT Indonesia dan Vietnam

Indonesia dan Vietnam sebagai anggota negara ASEAN masih mendominasi pasar TPT dunia, Amerika dan RRT. Dari hasil RCA TPT Indonesia (Tabel 2) selama lima tahun terakhir 2011-2015 Indonesia mempunyai rata-rata RCA sebesar 1,7 berarti daya saing yang cukup kuat. Demikian juga bila dilihat rata-rata RCA di kawasan ASEAN sebesar 1,1 artinya produk TPT Indonesia masih mempunyai daya saing yang relatif kuat karena lebih dari 1. Hal ini dimaksudkan sebagai perbandingan dengan negara tujuan yaitu AS dan RRT. Bila dilihat per HS maka produk Vegetable Textile Fibres HS 265 mempunyai RCA atau daya saing paling tinggi di kawasan Asean dengan RCA 2,0 dibanding produk lain. Produk lainnya adalah produk Women's Clothing, of Textile Fabrics HS 841 dengan RCA 2,3. Sedangkan daya saing TPT Indonesia dunia adalah produk Other Man-Made Fibres Suitable HS 267 dengan RCA 8,7. 
Tabel 2. Daya Saing (RCA) TPT Indonesia Terhadap Dunia dan ASEAN

\begin{tabular}{|c|c|c|c|c|c|c|c|c|c|c|c|c|}
\hline \multirow[b]{2}{*}{ Uraian } & \multicolumn{2}{|c|}{2011} & \multicolumn{2}{|c|}{2012} & \multicolumn{2}{|c|}{2013} & \multicolumn{2}{|c|}{2014} & \multicolumn{2}{|c|}{2015} & \multicolumn{2}{|c|}{ Average } \\
\hline & W & A & W & A & W & A & W & A & W & A & W & A \\
\hline [261] Silk & 0,0 & 0,0 & 0,0 & 0,0 & 0,0 & 0,0 & 0,0 & 0,0 & 0,0 & 0,0 & 0,0 & 0,0 \\
\hline [263] Cotton & 0,2 & 0,5 & 0,2 & 0,3 & 0,2 & 0,7 & 0,3 & 2,0 & 0,3 & 2,8 & 0,2 & 1,2 \\
\hline [265] Vegetable textile fibres, not spun & 1,6 & 0,8 & 1,6 & 1,6 & 0,8 & 1,5 & 1,0 & 2,8 & 1,2 & 5,0 & 1,2 & 2,0 \\
\hline [266] Synthetic fibres suitable for spinning & 1,3 & 0,6 & 1,6 & 0,8 & 1,3 & 0,8 & 2,4 & 1,3 & 1,9 & 1,2 & 1,6 & 0,8 \\
\hline [267] Other man-made fibres suitable & 9,7 & 1,5 & 8,5 & 1,3 & 9,1 & 1,3 & 7,6 & 1,2 & 7,7 & 1,8 & 8,7 & 1,4 \\
\hline [268] Wool and other animal hair & 0,0 & 0,4 & 0,0 & 0,0 & 0,0 & 0,0 & 0,0 & 0,0 & 0,0 & 0,0 & 0,0 & 0,1 \\
\hline [269] Worn clothing and other worn textile & 0,3 & 0,1 & 2,6 & 1,9 & 1,6 & 0,8 & 1,4 & 0,2 & 2,0 & 1,4 & 1,4 & 0,8 \\
\hline [841] Men's clothing of textile fabrics. & 2,2 & 1,9 & 2,3 & 1,9 & 2,3 & 1,8 & 2,2 & 1,8 & 2,4 & 1,8 & 2,3 & 1,9 \\
\hline [842] Women's clothing, of textile fabrics & 1,9 & 2,2 & 1,8 & 2,5 & 1,9 & 2,0 & 1,7 & 2,1 & 1,8 & 2,2 & 1,9 & 2,3 \\
\hline [843] Men's or boy's clothing, of textile, & 1,6 & 1,1 & 1,7 & 1,3 & 1,8 & 1,3 & 2,0 & 1,3 & 2,0 & 1,1 & 1,8 & 1,3 \\
\hline [844] Women's clothing, of textile, & 1,8 & 1,0 & 1,7 & 1,2 & 1,7 & 1,4 & 1,8 & 1,3 & 2,1 & 1,2 & 1,8 & 1,2 \\
\hline [845] Articles of apparel, of textile fabrics, & 1,5 & 1,1 & 1,6 & 0,7 & 1,6 & 1,1 & 1,5 & 1,1 & 1,7 & 1,1 & 1,6 & 1,1 \\
\hline [846] Clothing accessories & 0,7 & 0,3 & 0,8 & 0,3 & 0,8 & 0,3 & 0,9 & 0,3 & 1,0 & 0,4 & 0,8 & 0,3 \\
\hline [848] Articles of apparel, clothing access. & 1,1 & 0,7 & 1,1 & 0,8 & 1,0 & 0,6 & 1,0 & 0,5 & 1,2 & 0,7 & 1,1 & 0,6 \\
\hline Average & 1,7 & 0,9 & 1,8 & 1,0 & 1,7 & 1,0 & 1,7 & 1,1 & 1,8 & 1,5 & 1,7 & 1,1 \\
\hline
\end{tabular}

Sumber: UN Comtrade (2016), diolah ( $W=W$ orld, $A=A S E A N)$

Hasil RCA pada Tabel 3 HS 261 dengan rata-rata RCA sebesar menunjukkan nilai rata-rata daya saing TPT Vietnam dalam lima tahun terakhir mengungguli Indonesia. Nilai rata-rata RCA dunia untuk Vietnam adalah 3,1 lebih tinggi dari Indonesia yang sebesar 1,7. Demikian juga di level ASEAN, RCA Vietnam sebesar 2,0 lebih tinggi dari RCA Indonesia yang hanya sebesar 1,1. Produk TPT Vietnam yang mempunyai daya saing paling tinggi adalah Men's Clothing of Textile Fabrics HS 841 dan Men's or Boy's Clothing of Textile HS 843. Demikian juga produk TPT Vietnam yang mempunyai daya saing tinggi di kawasan ASEAN adalah produk Silk 14,6 selama 5 tahun terakhir. Selain itu juga produk Men's Clothing of Textile Fabrics HS 841.

Bila dibandingkan dengan TPT Indonesia, ternyata produk yang justru mempunyai daya saing tinggi dari Indonesia adalah produk Other Manmade Fibres Suitable HS 267, kebalikan dari Vietnam yang mempunyai daya saing paling rendah. Demikian juga produk Silk dengan HS 261 dari Vietnam ternyata daya saingnya di kawasan ASEAN relatif tinggi, namun sebaliknya produk Silk dari Indonesia memiliki daya saing yang rendah. 
Tabel 3. Daya Saing (RCA) TPT Vietnam Terhadap Dunia dan ASEAN

\begin{tabular}{|c|c|c|c|c|c|c|c|c|c|c|c|c|}
\hline \multirow[t]{2}{*}{ Uraian } & \multicolumn{2}{|c|}{2011} & \multicolumn{2}{|c|}{2012} & \multicolumn{2}{|c|}{2013} & \multicolumn{2}{|c|}{2014} & \multicolumn{2}{|c|}{2015} & \multicolumn{2}{|c|}{ Average } \\
\hline & W & A & W & $\mathrm{A}$ & W & $\mathrm{A}$ & W & $\mathrm{A}$ & W & A & W & $\mathrm{A}$ \\
\hline [261] Silk & 0,6 & 19,3 & 0,6 & 8,1 & 0,6 & 16,1 & 0,2 & 15,2 & 0,5 & 14,5 & 0,6 & 14,6 \\
\hline [263] Cotton & 0,2 & 1,3 & 0,1 & 0,4 & 0,2 & 0,8 & 0,2 & 1,7 & 0,2 & 2,8 & 0,2 & 1,4 \\
\hline [265] Vegetable textile fibres, not spun. & 7,0 & 0,0 & 5,2 & 0,5 & 3,7 & 0,0 & 3,9 & 0,1 & 5,9 & 0,4 & 5,6 & 0,2 \\
\hline [266] Synthetic fibres suitable for spinning & 1,9 & 1,4 & 2,1 & 1,0 & 1,8 & 0,8 & 1,8 & 1,2 & 1,8 & 1,1 & 1,9 & 1,1 \\
\hline [267] Other man-made fibres suitable & 0,0 & 0,0 & 0,1 & 0,0 & 0,0 & 0,0 & 0,0 & 0,1 & 0,0 & 0,1 & 0,0 & 0,1 \\
\hline [268] Wool and other animal hair & 0,0 & 0,0 & 0,0 & 0,0 & 0,0 & 0,0 & 0,0 & 0,0 & 0,0 & 0,0 & 0,0 & 0,0 \\
\hline [269] Worn clothing and other worn textile & 0,5 & 0,3 & 0,5 & 0,2 & 0,4 & 0,2 & 0,5 & 0,2 & 0,6 & 0,2 & 0,4 & 0,2 \\
\hline [841] Men's clothing of textile fabrics. & 8,4 & 3,7 & 7,7 & 3,1 & 7,4 & 2,8 & 7,1 & 2,4 & 7,1 & 2,9 & 7,6 & 3,1 \\
\hline [842] Women's clothing, of textile fabrics & 6,5 & 1,4 & 6,3 & 1,2 & 6,2 & 1,3 & 5,6 & 1,5 & 5,2 & 1,4 & 6,1 & 1,3 \\
\hline [843] Men's or boy's clothing, of textile. & 6,9 & 1,3 & 6,1 & 1,4 & 5,8 & 1,6 & 6,0 & 1,9 & 5,9 & 1,6 & 6,4 & 1,5 \\
\hline [844] Women's clothing, of textile, knitted & 5,7 & 1,6 & 5,4 & 1,3 & 4,9 & 1,3 & 5,4 & 1,7 & 5,8 & 1,4 & 5,5 & 1,5 \\
\hline [845] Articles of apparel, of textile fabrics. & 5,1 & 1,3 & 5,1 & 1,0 & 5,0 & 1,7 & 4,8 & 1,8 & 4,9 & 1,6 & 5,1 & 1,4 \\
\hline [846] Clothing accessories, of textile & 1,4 & 0,6 & 1,3 & 0,7 & 1,4 & 0,8 & 1,4 & 1,0 & 1,3 & 1,0 & 1,4 & 0,8 \\
\hline [848] Articles of apparel, clothing access. & 2,1 & 0,9 & 1,9 & 1,0 & 1,8 & 1,0 & 1,8 & 1,0 & 1,8 & 0,9 & 2,0 & 1,0 \\
\hline Average & 3,3 & 2,4 & 3,0 & 1,4 & 2,8 & 2,0 & 2,8 & 2,1 & 2,9 & 2,1 & 3,1 & 2,0 \\
\hline
\end{tabular}

Sumber: UN Comtrade (2016), diolah ( $W=W$ orld, $A=A S E A N)$

Analisis selanjutnya analisis CMSA yang dimaksudkan untuk menunjukkan perhitungan yang mempunyai aspek tidak hanya melihat daya saing, namun melihat produkproduk utama dari produk TPT tersebut terhadap perubahan permintaan dunia atau negara mitra dagangnya, (Balassa, 1989). CMSA lebih menekankan analisis daya saing secara kompetitif antara Indonesia dan Vietnam ke negara tujuan AS dan RRT serta dapat melihat kemampuan daya saing TPT masing-masing guna memformulasikan strategi pada posisi yang menguntungkan khususnya bagi Indonesia. Penghitungan CMSA berdasar tiga kriteria sebagai berikut:

\section{1) Competitiveness Effect}

Daya saing TPT Indonesia dan Vietnam tujuan ekspor RRT

TPT Indonesia dan Vietnam untuk tujuan ekspor ke RRT tidak mempunyai daya saing untuk setiap itemnya (Tabel 4). Artinya bahwa produk ekspor TPT kedua negara saat ini belum dapat menembus pasar di RRT, kalaupun sudah dapat menembus pasar di RRT namun dalam jumlah yang masih relatif kecil. Hal ini dapat dilihat dari data CE Indonesia dan Vietnam per tahun selama lima tahun dari 2011 sampai dengan 2015 mempunyai nilai daya saing nol. Demikian juga CE selama lima tahun juga mempunyai nilai daya saing nol. 
Tabel 4. Competitiveness Effect TPT Indonesia dan Vietnam di RRT, 2011-2015

\begin{tabular}{lrrrrrr}
\hline \multicolumn{1}{c}{ Tekstil dan Produk Tekstil } & 2011 & 2012 & 2013 & 2014 & 2015 & CE 5 th \\
\hline [261] Silk & 0,00 & 0,00 & 0,00 & 0,00 & 0,00 & 0,0000 \\
[263] Cotton & 0,00 & 0,00 & 0,00 & 0,00 & 0,00 & 0,0000 \\
[265] Vegetable textile fibres, not spun; waste of them & 0,00 & 0,00 & 0,00 & 0,00 & 0,00 & 0,0000 \\
[266] Synthetic fibres suitable for spinning & 0,00 & 0,00 & 0,00 & 0,00 & 0,00 & 0,0000 \\
[267] Other man-made fibres suitable for spinning & 0,00 & 0,00 & 0,00 & 0,00 & 0,00 & 0,0000 \\
[268] Wool and other animal hair (incl. wool tops) & 0,00 & 0,00 & 0,00 & 0,00 & 0,00 & 0,0000 \\
[269] Worn clothing and other worn textile articles & 0,00 & 0,00 & 0,00 & 0,00 & 0,00 & 0,0000 \\
[841] Men's clothing of textile fabrics, not knitted & 0,00 & 0,00 & 0,00 & 0,00 & 0,00 & 0,0000 \\
[842] Women's clothing, of textile fabrics & 0,00 & 0,00 & 0,00 & 0,00 & 0,00 & 0,0000 \\
[843] Men's or boy's clothing, of textile, knitted, croche. & 0,00 & 0,00 & 0,00 & 0,00 & 0,00 & 0,0000 \\
[844] Women's clothing, of textile, knitted or crocheted & 0,00 & 0,00 & 0,00 & 0,00 & 0,00 & 0,0000 \\
[845] Articles of apparel, of textile fabrics, n.e.s. & 0,00 & 0,00 & 0,00 & 0,00 & 0,00 & 0,0000 \\
[846] Clothing accessories, of textile fabrics & 0,00 & 0,00 & 0,00 & 0,00 & 0,00 & 0,0000 \\
[848] Articles of apparel, clothing access., excluding textile & 0,00 & 0,00 & 0,00 & 0,00 & 0,00 & 0,0000 \\
[841] Men's clothing of textile fabrics, not knitted & 0,00 & 0,00 & 0,00 & 0,00 & 0,00 & 0,0000 \\
[842] Women's clothing, of textile fabrics & 0,00 & 0,00 & 0,00 & 0,00 & 0,00 & 0,0000 \\
[843] Men's or boy's clothing, of textile, knitted, croche. & 0,00 & 0,00 & 0,00 & 0,00 & 0,00 & 0,0000 \\
[844] Women's clothing, of textile, knitted or crocheted & 0,00 & 0,00 & 0,00 & 0,00 & 0,00 & 0,0000 \\
[845] Articles of apparel, of textile fabrics, n.e.s. & 0,00 & 0,00 & 0,00 & 0,00 & 0,00 & 0,0000 \\
[846] Clothing accessories, of textile fabrics & 0,00 & 0,00 & 0,00 & 0,00 & 0,00 & 0,0000 \\
[848] Articles of apparel, clothing access., excluding textile & 0,00 & 0,00 & 0,00 & 0,00 & 0,00 & 0,0000 \\
\hline
\end{tabular}

Sumber : UN Comtrade (2016), diolah

Tabel 4 hasil RCA Indonesia dan Vietnam adalah nol sehingga tabel disatukan. Hasil RCA ini menunjukkan bahwa kedua negara belum dapat menembus secara signifikan di pasar ekspor RRT. Salah satu sebabnya antara lain sulitnya akses untuk dapat menembus pasar RRT karena adanya hambatan tarif dan non tarif. Disisi lain masalah efesiensi merupakan masalah krusial dua negara ini untuk dapat menembus pasar ekspor RRT.

\section{Daya saing TPT Indonesia Tujuan}

\section{Ekspor Amerika Serikat}

Pada Tabel 5, ternyata daya saing TPT Indonesia untuk tujuan ekspor ke AS bervariasi ada beberapa barang yang mempunyai daya saing dan ada beberapa barang yang tidak mempunyai daya saing. Hal ini terlihat dari data CE Indonesia selama 5 tahun dari 2011 sampai dengan 2015, beberapa item barang mempunyai indeks CE yang tinggi antara lain 
Vegetable Textile Fibres HS 265, Other

Textile Fabrics, Woven HS 652, Tulles,

Trimming, Lace HS 656, Special Yam, Special Textile Fabrics HS 657, Made up Article, of Textile Material HS 658, Men's Clothing HS 841, Women's
Clothing HS 842, Clothing Accesories HS 846. Demikian juga bila dilihat Competitiveness Effect (CE) selama lima tahun juga mempunyai indek daya saing yang cukup tinggi untuk item-item tersebut.

Tabel 5. Commpetitiveness Effect TPT Indonesia di Amerika Serikat, 2011-2015

\begin{tabular}{|c|c|c|c|c|c|c|}
\hline Tekstil dan Produk Tekstil & 2011 & 2012 & 2013 & 2014 & 2015 & CE 5 th \\
\hline [261] Silk & 0,00000 & 0,00000 & 0,00000 & 0,00000 & 0,00000 & 0,00000 \\
\hline [263] Cotton & $-4,48 \mathrm{E}-08$ & $-9,96 \mathrm{E}-08$ & $-4,34 \mathrm{E}-08$ & $2,002 E-08$ & $-1,83 \mathrm{E}-08$ & $-1,86 \mathrm{E}-07$ \\
\hline [265] Vegetable textile fibres, not spun; waste of them & $6,607 \mathrm{E}-10$ & 1,395E-09 & $-1,58 \mathrm{E}-09$ & $6,37 \mathrm{E}-12$ & $3,888 \mathrm{E}-10$ & $8,748 \mathrm{E}-10$ \\
\hline [266] Synthetic fibres suitable for spinning & $-3,5 \mathrm{E}-07$ & $-7,26 \mathrm{E}-08$ & $-1,82 \mathrm{E}-07$ & $-1,95 \mathrm{E}-07$ & $-1,11 \mathrm{E}-07$ & $-9,11 \mathrm{E}-07$ \\
\hline [267] Other man-made fibres suitable for spinning & $3,591 \mathrm{E}-07$ & $-4,18 \mathrm{E}-07$ & $-3,78 \mathrm{E}-07$ & $-1,81 \mathrm{E}-07$ & $-2,85 \mathrm{E}-07$ & $-9,03 E-07$ \\
\hline [268] Wool and other animal hair (incl. wool tops) & 0,00000 & 0,00000 & 0,00000 & 0,00000 & $-6,37 \mathrm{E}-10$ & 0,00000 \\
\hline [269] Worn clothing and other worn textile articles & $-4,45 \mathrm{E}-11$ & $2,019 \mathrm{E}-11$ & 0,0000 & 0,0000 & $7,469 \mathrm{E}-10$ & 0,00000 \\
\hline [651] Textile yarn & $-8,38 \mathrm{E}-08$ & $3,432 \mathrm{E}-07$ & $-4,93 \mathrm{E}-07$ & $-1,34 \mathrm{E}-06$ & $5,504 \mathrm{E}-07$ & $-1,02 \mathrm{E}-06$ \\
\hline [652] Cotton fabrics, woven & 4,93E-08 & $1,989 \mathrm{E}-07$ & $-1,58 \mathrm{E}-07$ & $-3,7 \mathrm{E}-07$ & $1,432 \mathrm{E}-07$ & $-1,36 \mathrm{E}-07$ \\
\hline [653] Fabrics, woven, of man-made fabrics & $-1 \mathrm{E}-07$ & $-7,46 \mathrm{E}-09$ & $-7,79 \mathrm{E}-08$ & $-5,32 \mathrm{E}-08$ & 1,094E-07 & $-1,3 \mathrm{E}-07$ \\
\hline [654] Other textile fabrics, woven & 1,958E-09 & $1,687 \mathrm{E}-08$ & $-1,95 \mathrm{E}-08$ & 3,805E-08 & $-1,37 E-08$ & $2,36 \mathrm{E}-08$ \\
\hline [655] Knitted or crocheted fabrics, n.e.s. & $-2,37 \mathrm{E}-07$ & 2,668E-09 & $-9,65 E-08$ & $-4,48 \mathrm{E}-08$ & $1,145 \mathrm{E}-08$ & $-3,64 \mathrm{E}-07$ \\
\hline $\begin{array}{l}\text { [656] Tulles, trimmings, lace, ribbons \& other small } \\
\text { wares }\end{array}$ & $2,432 \mathrm{E}-10$ & $9,792 \mathrm{E}-08$ & $3,463 \mathrm{E}-09$ & $-1,83 E-08$ & $-6,71 \mathrm{E}-08$ & $1,629 \mathrm{E}-08$ \\
\hline [657] Special yarn, special textile fabrics \& related & $-7,15 \mathrm{E}-08$ & $-3,88 \mathrm{E}-08$ & $9,989 \mathrm{E}-08$ & $3,008 \mathrm{E}-07$ & $7,69 \mathrm{E}-08$ & $3,672 \mathrm{E}-07$ \\
\hline [658] Made-up articles, of textile materials, n.e.s. & $7,139 \mathrm{E}-07$ & $-7,42 \mathrm{E}-08$ & $1,432 \mathrm{E}-07$ & $-1,59 \mathrm{E}-07$ & 2,922E-08 & $6,536 \mathrm{E}-07$ \\
\hline [659] Floor coverings, etc. & $-9,2 \mathrm{E}-08$ & $-8,25 E-08$ & $4,65 \mathrm{E}-08$ & $-2,6 \mathrm{E}-07$ & 4,848E-09 & $-3,83 \mathrm{E}-07$ \\
\hline [841] Men's clothing of textile fabrics, not knitted & $1,379 \mathrm{E}-06$ & $1,873 \mathrm{E}-06$ & $-1,43 \mathrm{E}-07$ & $-2,39 E-06$ & 3,711E-06 & 4,43E-06 \\
\hline [842] Women's clothing, of textile fabrics & $-1,68 E-06$ & $3,723 \mathrm{E}-06$ & $3,059 \mathrm{E}-06$ & $-8,63 E-06$ & $5,261 \mathrm{E}-06$ & $1,73 \mathrm{E}-06$ \\
\hline [843] Men's or boy's clothing, of textile, knitted, croche. & $-1,39 E-06$ & $2,726 \mathrm{E}-06$ & $-7,79 \mathrm{E}-07$ & $-4,24 \mathrm{E}-06$ & 1,617E-07 & $-3,53 E-06$ \\
\hline [844] Women's clothing, of textile, knitted or crocheted & $-4,09 \mathrm{E}-07$ & 4,963E-06 & $-2,67 \mathrm{E}-06$ & $4,655 \mathrm{E}-07$ & $8,636 \mathrm{E}-07$ & $3,208 \mathrm{E}-06$ \\
\hline [845] Articles of apparel, of textile fabrics, n.e.s. & $-2,83 E-06$ & $1,038 \mathrm{E}-05$ & $-1,4 \mathrm{E}-05$ & $-8,61 \mathrm{E}-06$ & 6,587E-06 & $-8,48 \mathrm{E}-06$ \\
\hline [846] Clothing accessories, of textile fabrics & $-2,73 \mathrm{E}-07$ & $4,021 \mathrm{E}-07$ & $-1,81 \mathrm{E}-07$ & $7,122 \mathrm{E}-07$ & $4,12 \mathrm{E}-07$ & 1,072E-06 \\
\hline [848] Articles of apparel, clothing access., & $-5,49 \mathrm{E}-07$ & 4,744E-07 & $-8,5 \mathrm{E}-07$ & $-5,37 \mathrm{E}-07$ & $1,312 \mathrm{E}-06$ & $-1,49 \mathrm{E}-07$ \\
\hline
\end{tabular}

Sumber : UN Comtrade (2016), diolah

\section{Daya saing TPT Vietnam Tujuan Ekspor Amerika Serikat}

Komoditas TPT Vietnam untuk tujuan ekspor ke Amerika Serikat bervariasi, selama beberapa tahun ada beberapa barang yang mempunyai daya saing dan ada beberapa barang yang tidak mempunyai daya saing. Hal ini terlihat dari data CE Indonesia selama lima tahun (2011-2015) beberapa jenis barang mempunyai indeks CE yang tinggi antara Vegetable Textile Fibres 
HS 265, Cotton Fabric HS 652, Floor Covering HS 659, Men's Clothing HS

841, Women's Clothing HS 842 (Tabel
6). Namun demikian CE selama lima tahun mempunyai daya saing yang rendah untuk item-item tersebut.

Tabel 6. Commpetitiveness Effect TPT Vietnam di Amerika Serikat, 2011-2015

\begin{tabular}{|c|c|c|c|c|c|c|}
\hline Tekstil dan Produk Tekstil & 2011 & 2012 & 2013 & 2014 & 2015 & CE 5 th \\
\hline [261] Silk & 0,000000 & 0,000000 & 0,000000 & 0,000000 & 0,000000 & 0,000000 \\
\hline [263] Cotton & 0,000000 & 0,000000 & 0,000000 & 0,000000 & 0,000000 & 0,000000 \\
\hline [265] Vegetable textile fibres, not spun; waste of them & 0,0003527 & $-0,000999$ & $8,1 \mathrm{E}-05$ & 0,0001675 & $-3,05 E-05$ & $-0,000428$ \\
\hline [266] Synthetic fibres suitable for spinning & 0,0193175 & $-0,014761$ & $-0,006847$ & 0,0152901 & $-0,005428$ & 0,0075727 \\
\hline [267] Other man-made fibres suitable for spinning & 0,000000 & 0,000000 & 0,000000 & $-1,92 \mathrm{E}-06$ & 0,00000 & 0,00000 \\
\hline [268] Wool and other animal hair (incl. wool tops) & 0,000000 & 0,000000 & 0,000000 & 0,00000 & 0,00000 & 0,00000 \\
\hline [269] Worn clothing and other worn textile articles & $6,09 \mathrm{E}-05$ & $-0,00017$ & $-5,8 \mathrm{E}-06$ & 2,707E-05 & $9,257 \mathrm{E}-06$ & $-7,83 \mathrm{E}-05$ \\
\hline [651] Textile yarn & 0,0362963 & $-0,041452$ & 0,0033757 & 0,0099818 & $-0,015578$ & $-0,007377$ \\
\hline [652] Cotton fabrics, woven & 0,0003756 & $-0,000418$ & $3,284 \mathrm{E}-06$ & $5,839 \mathrm{E}-05$ & $-0,000105$ & $-8,65 \mathrm{E}-05$ \\
\hline [653] Fabrics, woven, of man-made fabrics & 0,0218572 & $-0,017705$ & 0,0009621 & 0,0133738 & $-0,009191$ & 0,0092971 \\
\hline [654] Other textile fabrics, woven & 0,0005604 & $-0,000727$ & $-0,000116$ & $8,002 E-05$ & $-1,04 \mathrm{E}-05$ & $-0,000213$ \\
\hline [655] Knitted or crocheted fabrics, n.e.s. & 0,0087084 & $-0,007918$ & $-0,002091$ & 0,0041955 & $-0,002522$ & 0,0003734 \\
\hline [656] Tulles, trimmings, lace, ribbons \& other small wares & 0,0042127 & $-0,003442$ & $-1,6 \mathrm{E}-05$ & 0,0041337 & $-0,001839$ & 0,0030495 \\
\hline [657] Special yarn, special textile fabrics \& related & 0,3815246 & $-0,377766$ & $-0,0048$ & 0,1451722 & $-0,126067$ & 0,0180642 \\
\hline [658] Made-up articles, of textile materials, n.e.s. & 0,1486107 & $-0,146923$ & $-0,007227$ & 0,0762774 & $-0,053576$ & 0,0171612 \\
\hline [659] Floor coverings, etc. & 5,799E-05 & $-0,000358$ & 7,381E-05 & 0,0007385 & $-0,000694$ & $-0,000182$ \\
\hline [841] Men's clothing of textile fabrics, not knitted & 1,740475 & $-1,715752$ & $-0,023035$ & 1,0105861 & $-0,687567$ & 0,3247075 \\
\hline [842] Women's clothing, of textile fabrics & 1,9768587 & $-1,954697$ & $-0,032792$ & 1,1055591 & $-0,769443$ & 0,3254861 \\
\hline [843] Men's or boy's clothing, of textile, knitted, croche. & 1,1072906 & $-1,00046$ & 0,0105919 & 0,7267496 & $-0,447099$ & 0,3970724 \\
\hline [844] Women's clothing, of textile, knitted or crocheted & 1,7898983 & $-1,643494$ & $-0,054885$ & 1,2810967 & $-0,862258$ & 0,5103582 \\
\hline [845] Articles of apparel, of textile fabrics, n.e.s. & 3,742902 & $-3,677185$ & $-0,139435$ & 2,1568252 & $-1,376858$ & 0,7062495 \\
\hline [846] Clothing accessories, of textile fabrics & 0,1062538 & $-0,088494$ & $-0,002155$ & 0,0856935 & $-0,051061$ & 0,0502373 \\
\hline [848] Articles of apparel, clothing access., excluding textile & 0,24487 & $-0,243078$ & $-0,012278$ & 0,1316389 & $-0,078041$ & 0,0431111 \\
\hline
\end{tabular}

Sumber : UN Comtrade (2016), diolah

Dari data CE dua negara tersebut baik Indonesia dan Vietnam telah dapat menembus pasar ekspor Amerika Serikat. Namun untuk daya saing beberapa jenis barang ekspor Indonesia ternyata lebih baik dibanding daya saing barang ekspor Vietnam ke Amerika Serikat. Hal ini menjadi peluang bagi barang ekspor Indonesia untuk terus meningkatkan daya saing masuk di pasaran Amerika Serikat.

\section{2) Initial Specialization}

\section{Initial Specialization Ekspor TPT Indonesia ke RRT}

Initial Specialization menunjukkan pengembangan produk-produk tertentu yang memiliki ciri khas tertentu dari suatu pasar dalam merespon 
perubahan permintaan dunia. Tabel 7 menunjukkan bahwa selama lima tahun yaitu 2011 sampai dengan 2015 tidak ada produk tekstil yang menjadi komoditas baru TPT yang diekspor
Indonesia ke RRT. Sedangkan indeks IS yang positif hanya ditunjukkan di tahun 2011 dan tahun 2013, namun tahun-tahun berikutnya menjadi negatif.

Tabel 7. Initial Specialization TPT Indonesia di RRT, 2011-2015

\begin{tabular}{|c|c|c|c|c|c|c|}
\hline Tekstil dan Produk Tekstil & 2011 & 2012 & 2013 & 2014 & 2015 & IS 5 th \\
\hline [261] Silk & 0,00000 & 0,00000 & 0,00000 & 0,00000 & 0,0000 & 0,00000 \\
\hline [263] Cotton & $8,29 E-08$ & $-1,5 \mathrm{E}-08$ & $1,04 \mathrm{E}-08$ & $-5,5 \mathrm{E}-08$ & $-3,1 \mathrm{E}-08$ & $-7,1 \mathrm{E}-09$ \\
\hline [265] Vegetable textile fibres, not spun; waste of them & $3,06 \mathrm{E}-07$ & $-5,4 \mathrm{E}-08$ & $3,84 \mathrm{E}-08$ & $-2 \mathrm{E}-07$ & $-1,1 \mathrm{E}-07$ & $-2,6 \mathrm{E}-08$ \\
\hline [266] Synthetic fibres suitable for spinning & $3,36 \mathrm{E}-08$ & $-5,9 \mathrm{E}-09$ & $4,22 \mathrm{E}-09$ & $-2,2 \mathrm{E}-08$ & $-1,2 \mathrm{E}-08$ & $-2,9 \mathrm{E}-09$ \\
\hline [267] Other man-made fibres suitable for spinning & 1,57E-06 & $-2,7 \mathrm{E}-07$ & 1,97E-07 & $-1 \mathrm{E}-06$ & $-5,8 \mathrm{E}-07$ & $-1,4 \mathrm{E}-07$ \\
\hline [268] Wool and other animal hair (incl. wool tops) & 0,00000 & 0,00000 & 0,00000 & 0,00000 & 0,00000 & 0,00000 \\
\hline [269] Worn clothing and other worn textile articles & $2,57 \mathrm{E}-07$ & $-4,5 \mathrm{E}-08$ & $3,22 \mathrm{E}-08$ & $-1,7 \mathrm{E}-07$ & $-9,5 \mathrm{E}-08$ & $-2,2 \mathrm{E}-08$ \\
\hline [651] Textile yarn & 2,81E-06 & $-4,9 \mathrm{E}-07$ & $3,53 \mathrm{E}-07$ & $-1,9 \mathrm{E}-06$ & $-1 E-06$ & $-2,4 \mathrm{E}-07$ \\
\hline [652] Cotton fabrics, woven & $3,84 \mathrm{E}-07$ & $-6,7 \mathrm{E}-08$ & $4,81 \mathrm{E}-08$ & $-2,6 \mathrm{E}-07$ & $-1,4 \mathrm{E}-07$ & $-3,3 \mathrm{E}-08$ \\
\hline [653] Fabrics, woven, of man-made fabrics & $5,85 \mathrm{E}-07$ & $-1 \mathrm{E}-07$ & $7,34 \mathrm{E}-08$ & $-3,9 \mathrm{E}-07$ & $-2,2 \mathrm{E}-07$ & $-5 \mathrm{E}-08$ \\
\hline [654] Other textile fabrics, woven & $2,29 \mathrm{E}-10$ & $-4 \mathrm{E}-11$ & $2,88 \mathrm{E}-11$ & $-1,5 \mathrm{E}-10$ & $-8,5 \mathrm{E}-11$ & $-2 \mathrm{E}-11$ \\
\hline [655] Knitted or crocheted fabrics, n.e.s. & $2,38 \mathrm{E}-07$ & $-4,2 \mathrm{E}-08$ & 2,98E-08 & $-1,6 \mathrm{E}-07$ & $-8,8 \mathrm{E}-08$ & $-2,1 \mathrm{E}-08$ \\
\hline [656] Tulles, trimmings, lace, ribbons \& other small wares & $9,33 \mathrm{E}-09$ & $-1,6 \mathrm{E}-09$ & 1,17E-09 & $-6,2 \mathrm{E}-09$ & $-3,5 \mathrm{E}-09$ & $-8 \mathrm{E}-10$ \\
\hline [657] Special yarn, special textile fabrics \& related & $3,55 \mathrm{E}-07$ & $-6,2 \mathrm{E}-08$ & $4,45 \mathrm{E}-08$ & $-2,4 \mathrm{E}-07$ & $-1,3 \mathrm{E}-07$ & $-3,1 \mathrm{E}-08$ \\
\hline [658] Made-up articles, of textile materials, n.e.s. & 1,99E-07 & $-3,5 \mathrm{E}-08$ & 2,49E-08 & $-1,3 \mathrm{E}-07$ & $-7,4 \mathrm{E}-08$ & $-1,7 \mathrm{E}-08$ \\
\hline [659] Floor coverings, etc. & 2,33E-08 & $-4,1 \mathrm{E}-09$ & 2,92E-09 & $-1,6 \mathrm{E}-08$ & $-8,6 \mathrm{E}-09$ & $-2 \mathrm{E}-09$ \\
\hline [841] Men's clothing of textile fabrics, not knitted & $4,16 \mathrm{E}-07$ & $-7,3 \mathrm{E}-08$ & $5,23 \mathrm{E}-08$ & $-2,8 \mathrm{E}-07$ & $-1,5 \mathrm{E}-07$ & $-3,6 \mathrm{E}-08$ \\
\hline [842] Women's clothing, of textile fabrics & $3,14 \mathrm{E}-07$ & $-5,5 \mathrm{E}-08$ & $3,94 \mathrm{E}-08$ & $-2,1 \mathrm{E}-07$ & $-1,2 \mathrm{E}-07$ & $-2,7 \mathrm{E}-08$ \\
\hline [843] Men's or boy's clothing, of textile, knitted, croche. & $9,92 \mathrm{E}-08$ & $-1,7 \mathrm{E}-08$ & $1,24 \mathrm{E}-08$ & $-6,6 \mathrm{E}-08$ & $-3,7 \mathrm{E}-08$ & $-8,6 \mathrm{E}-09$ \\
\hline [844] Women's clothing, of textile, knitted or crocheted & $1,43 \mathrm{E}-07$ & $-2,5 \mathrm{E}-08$ & 1,79E-08 & $-9,5 \mathrm{E}-08$ & $-5,3 \mathrm{E}-08$ & $-1,2 \mathrm{E}-08$ \\
\hline [845] Articles of apparel, of textile fabrics, n.e.s. & $3,83 \mathrm{E}-07$ & $-6,7 \mathrm{E}-08$ & 4,81E-08 & $-2,6 \mathrm{E}-07$ & $-1,4 \mathrm{E}-07$ & $-3,3 E-08$ \\
\hline [846] Clothing accessories, of textile fabrics & $3,41 \mathrm{E}-08$ & $-6 \mathrm{E}-09$ & 4,27E-09 & $-2,3 \mathrm{E}-08$ & $-1,3 \mathrm{E}-08$ & $-2,9 \mathrm{E}-09$ \\
\hline [848] Articles of apparel, clothing access., excluding textile & $6,51 \mathrm{E}-08$ & $-1,1 \mathrm{E}-08$ & $8,17 \mathrm{E}-09$ & $-4,3 \mathrm{E}-08$ & $-2,4 \mathrm{E}-08$ & $-5,6 \mathrm{E}-09$ \\
\hline
\end{tabular}

Sumber : UN Comtrade (2016), diolah

\section{Initial Specialization Ekspor TPT Vietnam ke RRT}

Tabel 8 menunjukkan bahwa selama lima tahun (2011-2015) hampir seluruh TPT yang menjadi komoditas baru TPT yang diekspor Vietnam ke RRT menunjukkan IS positif artinya jenisjenis barang tersebut memiliki kekuatan memasuki pasar di negara RRT kecuali jenis produk Silk HS 261 dan Wool and Other HS 268 yang mempunyai IS nol selama lima tahun. 
Tabel 8. Initial Specialization TPT Vietnam di RRT, 2011-2015

\begin{tabular}{|c|c|c|c|c|c|c|}
\hline Tekstil dan Produk Tekstil & 2011 & 2012 & 2013 & 2014 & 2015 & IS 5 th \\
\hline [261] Silk & 0,00000 & 0,00000 & 0,00000 & 0,00000 & 0,00000 & 0,00000 \\
\hline [263] Cotton & $2,9 \mathrm{E}-08$ & $9,11 \mathrm{E}-09$ & $2,48 \mathrm{E}-09$ & 1,27E-08 & $5,44 \mathrm{E}-08$ & $1,08 \mathrm{E}-07$ \\
\hline [265] Vegetable textile fibres, not spun; waste of them & $5,78 \mathrm{E}-07$ & $1,81 \mathrm{E}-07$ & 4,93E-08 & $2,53 \mathrm{E}-07$ & $1,08 \mathrm{E}-06$ & $2,14 \mathrm{E}-06$ \\
\hline [266] Synthetic fibres suitable for spinning & $2,42 \mathrm{E}-09$ & $7,6 \mathrm{E}-10$ & $2,07 \mathrm{E}-10$ & 1,06E-09 & 4,54E-09 & 8,99E-09 \\
\hline [267] Other man-made fibres suitable for spinning & $6,06 \mathrm{E}-09$ & $1,9 \mathrm{E}-09$ & $5,17 \mathrm{E}-10$ & $2,65 \mathrm{E}-09$ & $1,13 \mathrm{E}-08$ & $2,25 \mathrm{E}-08$ \\
\hline [268] Wool and other animal hair (incl. wool tops) & 0,00000 & 0,00000 & 0,00000 & 0,00000 & 0,00000 & 0,00000 \\
\hline [269] Worn clothing and other worn textile articles & $2,01 \mathrm{E}-07$ & $6,32 \mathrm{E}-08$ & $1,72 \mathrm{E}-08$ & 8,81E-08 & $3,77 \mathrm{E}-07$ & 7,47E-07 \\
\hline [651] Textile yarn & 9,94E-06 & $3,12 \mathrm{E}-06$ & $8,48 \mathrm{E}-07$ & $4,35 \mathrm{E}-06$ & $1,86 \mathrm{E}-05$ & 3,69E-05 \\
\hline [652] Cotton fabrics, woven & 4,94E-08 & $1,55 \mathrm{E}-08$ & 4,21E-09 & $2,16 \mathrm{E}-08$ & $9,24 \mathrm{E}-08$ & $1,83 \mathrm{E}-07$ \\
\hline [653] Fabrics, woven, of man-made fabrics & $4,75 \mathrm{E}-07$ & $1,49 \mathrm{E}-07$ & $4,05 \mathrm{E}-08$ & $2,08 \mathrm{E}-07$ & $8,9 \mathrm{E}-07$ & $1,76 \mathrm{E}-06$ \\
\hline [654] Other textile fabrics, woven & $4,62 \mathrm{E}-09$ & 1,45E-09 & $3,94 \mathrm{E}-10$ & $2,02 \mathrm{E}-09$ & $8,65 E-09$ & 1,71E-08 \\
\hline [655] Knitted or crocheted fabrics, n.e.s. & 4,57E-07 & $1,43 \mathrm{E}-07$ & $3,9 \mathrm{E}-08$ & $2 \mathrm{E}-07$ & $8,55 \mathrm{E}-07$ & $1,69 \mathrm{E}-06$ \\
\hline [656] Tulles, trimmings, lace, ribbons & $2,79 E-08$ & $8,76 \mathrm{E}-09$ & $2,38 \mathrm{E}-09$ & $1,22 \mathrm{E}-08$ & $5,23 E-08$ & $1,04 \mathrm{E}-07$ \\
\hline [657] Special yarn, special textile fabrics \& related & $4,61 \mathrm{E}-07$ & $1,44 \mathrm{E}-07$ & $3,93 E-08$ & 2,01E-07 & $8,62 \mathrm{E}-07$ & 1,71E-06 \\
\hline [658] Made-up articles, of textile materials, n.e.s. & $9,88 \mathrm{E}-08$ & $3,1 \mathrm{E}-08$ & $8,42 \mathrm{E}-09$ & $4,32 \mathrm{E}-08$ & $1,85 \mathrm{E}-07$ & $3,66 \mathrm{E}-07$ \\
\hline [659] Floor coverings, etc. & 1,01E-09 & $3,16 \mathrm{E}-10$ & $8,59 \mathrm{E}-11$ & $4,41 \mathrm{E}-10$ & 1,89E-09 & $3,74 \mathrm{E}-09$ \\
\hline [841] Men's clothing of textile fabrics, not knitted & $1,13 \mathrm{E}-06$ & $3,56 \mathrm{E}-07$ & $9,67 \mathrm{E}-08$ & $4,96 \mathrm{E}-07$ & $2,12 \mathrm{E}-06$ & $4,2 \mathrm{E}-06$ \\
\hline [842] Women's clothing, of textile fabrics & 7,91E-07 & $2,48 \mathrm{E}-07$ & $6,74 \mathrm{E}-08$ & $3,46 \mathrm{E}-07$ & $1,48 \mathrm{E}-06$ & 2,93E-06 \\
\hline [843] Men's or boy's clothing, of textile, knitted, croche. & $1,59 \mathrm{E}-07$ & 4,99E-08 & $1,36 \mathrm{E}-08$ & $6,96 \mathrm{E}-08$ & $2,98 \mathrm{E}-07$ & $5,9 \mathrm{E}-07$ \\
\hline [844] Women's clothing, of textile, knitted or crocheted & 2,99E-07 & $9,38 \mathrm{E}-08$ & $2,55 \mathrm{E}-08$ & $1,31 \mathrm{E}-07$ & $5,6 \mathrm{E}-07$ & 1,11E-06 \\
\hline [845] Articles of apparel, of textile fabrics, n.e.s. & $9,55 \mathrm{E}-07$ & $3 \mathrm{E}-07$ & $8,15 \mathrm{E}-08$ & $4,18 \mathrm{E}-07$ & 1,79E-06 & $3,54 \mathrm{E}-06$ \\
\hline [846] Clothing accessories, of textile fabrics & $1,45 \mathrm{E}-08$ & $4,54 \mathrm{E}-09$ & 1,24E-09 & $6,33 \mathrm{E}-09$ & 2,71E-08 & $5,37 \mathrm{E}-08$ \\
\hline [848] Articles of apparel, clothing access. & $6,99 \mathrm{E}-08$ & 2,19E-08 & 5,96E-09 & $3,06 \mathrm{E}-08$ & $1,31 \mathrm{E}-07$ & 2,59E-07 \\
\hline
\end{tabular}

Sumber : UN Comtrade (2016) diolah

Produk ekspor TPT antara Indonesia dan Vietnam ternyata pengembangan produk TPT Vietnam lebih tinggi memasuki pasar ekspor RRT sedangkan pengembangan produk ekspor TPT Indonesia ke RRT masih relatif kecil. Hal ini terlihat nilai IS yang positif dan lebih tinggi dibandingkan dengan Indonesia. Hasil IS jenis produk ekspor Indonesia ke RRT tahun 2011 saja yang positif, namun sampai tahun 2015 IS Indonesia mempunyai hasil negatif, yang berarti pengembangan jenis produk TPT Indonesia masih mengalami kesulitan.

\section{Initial Specialization Ekspor TPT} Indonesia ke Amerika Serikat

Tabel 9 menunjukkan bahwa selama lima tahun yaitu (2011-2015) hampir seluruh TPT yang menjadi komoditas baru TPT yang diekspor Indonesia ke Amerika Serikat menunjukkan IS positif kecuali produk Silk HS 261 dan Wool and Other HS 268. 
Tabel 9. Initial Specialization TPT Indonesia di Amerika Serikat, 2011-2015

\begin{tabular}{|c|c|c|c|c|c|c|}
\hline Tekstil dan Produk Tekstil & 2011 & 2012 & 2013 & 2014 & 2015 & IS 5 th \\
\hline [261] Silk & 0,00000 & 0,00000 & 0,00000 & 0,00000 & 0,00000 & 0,00000 \\
\hline [263] Cotton & $2,01 \mathrm{E}-08$ & $-1,4 \mathrm{E}-08$ & $7,35 \mathrm{E}-09$ & $7,25 \mathrm{E}-09$ & $-5,7 \mathrm{E}-09$ & $1,45 \mathrm{E}-08$ \\
\hline [265] Vegetable textile fibres, not spun; waste of them & $9,59 \mathrm{E}-11$ & $-6,9 \mathrm{E}-11$ & $3,5 \mathrm{E}-11$ & $3,46 \mathrm{E}-11$ & $-2,7 \mathrm{E}-11$ & $6,94 \mathrm{E}-11$ \\
\hline [266] Synthetic fibres suitable for spinning & $1,84 \mathrm{E}-07$ & $-1,3 \mathrm{E}-07$ & $6,72 \mathrm{E}-08$ & $6,63 E-08$ & $-5,2 E-08$ & $1,33 \mathrm{E}-07$ \\
\hline [267] Other man-made fibres suitable for spinning & $2,12 \mathrm{E}-07$ & $-1,5 \mathrm{E}-07$ & $7,73 E-08$ & $7,63 E-08$ & $-6 \mathrm{E}-08$ & $1,53 \mathrm{E}-07$ \\
\hline [268] Wool and other animal hair (incl. wool tops) & 0,00000 & 0,00000 & 0,00000 & 0,00000 & 0,00000 & 0,00000 \\
\hline [269] Worn clothing and other worn textile articles & $3,36 \mathrm{E}-12$ & $-2,4 \mathrm{E}-12$ & $1,23 E-12$ & $1,21 \mathrm{E}-12$ & $-9,6 \mathrm{E}-13$ & $2,43 \mathrm{E}-12$ \\
\hline [651] Textile yarn & $9,58 \mathrm{E}-07$ & $-6,9 \mathrm{E}-07$ & $3,5 \mathrm{E}-07$ & $3,45 \mathrm{E}-07$ & $-2,7 \mathrm{E}-07$ & $6,93 \mathrm{E}-07$ \\
\hline [652] Cotton fabrics, woven & $3,12 \mathrm{E}-07$ & $-2,2 \mathrm{E}-07$ & $1,14 \mathrm{E}-07$ & $1,12 \mathrm{E}-07$ & $-8,9 \mathrm{E}-08$ & $2,26 \mathrm{E}-07$ \\
\hline [653] Fabrics, woven, of man-made fabrics & $6,14 \mathrm{E}-08$ & $-4,4 \mathrm{E}-08$ & 2,24E-08 & 2,21E-08 & $-1,7 \mathrm{E}-08$ & $4,44 \mathrm{E}-08$ \\
\hline [654] Other textile fabrics, woven & 1,1E-09 & $-7,9 \mathrm{E}-10$ & $4,03 \mathrm{E}-10$ & $3,98 \mathrm{E}-10$ & $-3,1 \mathrm{E}-10$ & $7,98 \mathrm{E}-10$ \\
\hline [655] Knitted or crocheted fabrics, n.e.s. & $4,51 \mathrm{E}-08$ & $-3,2 \mathrm{E}-08$ & $1,65 \mathrm{E}-08$ & 1,63E-08 & $-1,3 \mathrm{E}-08$ & $3,26 \mathrm{E}-08$ \\
\hline [656] Tulles, trimmings, lace, ribbons \& other small wares & 1,71E-08 & $-1,2 \mathrm{E}-08$ & $6,24 \mathrm{E}-09$ & $6,15 \mathrm{E}-09$ & $-4,9 \mathrm{E}-09$ & $1,23 \mathrm{E}-08$ \\
\hline [657] Special yarn, special textile fabrics \& related & $7,94 \mathrm{E}-08$ & $-5,7 \mathrm{E}-08$ & 2,9E-08 & $2,86 \mathrm{E}-08$ & $-2,3 \mathrm{E}-08$ & $5,74 \mathrm{E}-08$ \\
\hline [658] Made-up articles, of textile materials, n.e.s. & $3,43 E-07$ & $-2,5 \mathrm{E}-07$ & $1,25 \mathrm{E}-07$ & $1,24 \mathrm{E}-07$ & $-9,8 \mathrm{E}-08$ & $2,48 \mathrm{E}-07$ \\
\hline [659] Floor coverings, etc. & $1,26 \mathrm{E}-07$ & $-9 \mathrm{E}-08$ & $4,59 \mathrm{E}-08$ & $4,53 \mathrm{E}-08$ & $-3,6 \mathrm{E}-08$ & $9,08 \mathrm{E}-08$ \\
\hline [841] Men's clothing of textile fabrics, not knitted & $5,62 E-06$ & $-4 \mathrm{E}-06$ & $2,05 E-06$ & 2,03E-06 & $-1,6 \mathrm{E}-06$ & 4,06E-06 \\
\hline [842] Women's clothing, of textile fabrics & $7,75 \mathrm{E}-06$ & $-5,6 \mathrm{E}-06$ & 2,83E-06 & 2,79E-06 & $-2,2 E-06$ & $5,61 E-06$ \\
\hline [843] Men's or boy's clothing, of textile, knitted, croche. & $3,23 E-06$ & $-2,3 E-06$ & $1,18 \mathrm{E}-06$ & $1,16 \mathrm{E}-06$ & $-9,2 \mathrm{E}-07$ & 2,33E-06 \\
\hline [844] Women's clothing, of textile, knitted or crocheted & $6,14 \mathrm{E}-06$ & $-4,4 \mathrm{E}-06$ & 2,24E-06 & 2,21E-06 & $-1,7 \mathrm{E}-06$ & 4,44E-06 \\
\hline [845] Articles of apparel, of textile fabrics, n.e.s. & $1,5 \mathrm{E}-05$ & $-1,1 \mathrm{E}-05$ & $5,49 E-06$ & $5,42 \mathrm{E}-06$ & $-4,3 \mathrm{E}-06$ & 1,09E-05 \\
\hline [846] Clothing accessories, of textile fabrics & $3,59 \mathrm{E}-07$ & $-2,6 \mathrm{E}-07$ & $1,31 \mathrm{E}-07$ & $1,29 \mathrm{E}-07$ & $-1 \mathrm{E}-07$ & $2,6 \mathrm{E}-07$ \\
\hline [848] Articles of apparel, clothing access., excluding textile & $1,06 \mathrm{E}-06$ & $-7,6 \mathrm{E}-07$ & $3,88 \mathrm{E}-07$ & $3,82 \mathrm{E}-07$ & $-3 \mathrm{E}-07$ & 7,67E-07 \\
\hline
\end{tabular}

Sumber : UN Comtrade (2016) diolah

\section{Initial Specialization Ekspor TPT} Vietnam ke Amerika Serikat

Untuk IS atas ekspor TPT Vietnam ke Amerika Serikat ternyata hanya ada 5 jenis yang bernilai positif artinya ada 5 pengembangan produk TPT Vietnam di pasaran Amerika Serikat yaitu Men's Clothing HS 841, Women's Clothing HS 842, Men's or Boy's Clothing of Textile Fabrics not Knitted or Crocheted HS 843, Women's
Clothing of Textile Knitted or Crocheted HS 844 dan Article of Apparel HS 845 (Tabel 10).

Berdasarkan indeks IS, produk TPT Vietnam lebih unggul di pasaran RRT dibanding Indonesia sedangkan di pasaran Amerika Serikat, Vietnam hanya beberapa produk TPT yang mulai dikembangkan sehingga dilihat dari indeks IS Indonesia masih menguasai pasar di Amerika Serikat. 
Tabel 10. Initial Specialization TPT Vietnam di Amerika Serikat, 2011-2015

\begin{tabular}{|c|c|c|c|c|c|c|}
\hline Tekstil dan Produk Tekstil & 2011 & 2012 & 2013 & 2014 & 2015 & IS 5 th \\
\hline [261] Silk & 0,0000 & 0,0000 & 0,0000 & 0,0000 & 0,0000 & 0,0000 \\
\hline [263] Cotton & 0,0000 & 0,0000 & 0,0000 & 0,0000 & 0,0000 & 0,0000 \\
\hline [265] Vegetable textile fibres, not spun; waste of them & 0,000198 & 0,000196 & 0,000294 & 0,000336 & 0,000452 & 0,001476 \\
\hline [266] Synthetic fibres suitable for spinning & 0,004617 & 0,004568 & 0,006867 & 0,007842 & 0,010563 & 0,034456 \\
\hline [267] Other man-made fibres suitable for spinning & 0,00000 & 0,00000 & 0,00000 & 0,00000 & 0,00000 & 0,00000 \\
\hline [268] Wool and other animal hair (incl. wool tops) & 0,00000 & 0,00000 & 0,00000 & 0,00000 & 0,00000 & 0,00000 \\
\hline [269] Worn clothing and other worn textile articles & $2,86 \mathrm{E}-05$ & 2,83E-05 & $4,25 E-05$ & 4,86E-05 & $6,54 \mathrm{E}-05$ & 0,000213 \\
\hline [651] Textile yarn & 0,008361 & 0,008272 & 0,012435 & 0,014201 & 0,019129 & 0,062397 \\
\hline [652] Cotton fabrics, woven & $8,56 \mathrm{E}-05$ & $8,47 \mathrm{E}-05$ & 0,000127 & 0,000145 & 0,000196 & 0,000639 \\
\hline [653] Fabrics, woven, of man-made fabrics & 0,004456 & 0,004408 & 0,006627 & 0,007568 & 0,010194 & 0,033253 \\
\hline [654] Other textile fabrics, woven & 0,000145 & 0,000144 & 0,000216 & 0,000247 & 0,000332 & 0,001084 \\
\hline [655] Knitted or crocheted fabrics, n.e.s. & 0,001874 & 0,001854 & 0,002787 & 0,003183 & 0,004287 & 0,013985 \\
\hline [656] Tulles, trimmings, lace, ribbons \& other small wares & 0,000956 & 0,000945 & 0,001421 & 0,001623 & 0,002186 & 0,007132 \\
\hline [657] Special yarn, special textile fabrics \& related & 0,08239 & 0,081516 & 0,122541 & 0,139939 & 0,1885 & 0,614885 \\
\hline [658] Made-up articles, of textile materials, n.e.s. & 0,035676 & 0,035298 & 0,053062 & 0,060596 & 0,081624 & 0,266255 \\
\hline [659] Floor coverings, etc. & $7,73 \mathrm{E}-05$ & $7,65 \mathrm{E}-05$ & 0,000115 & 0,000131 & 0,000177 & 0,000577 \\
\hline [841] Men's clothing of textile fabrics, not knitted & 0,407021 & 0,402703 & 0,605377 & 0,691325 & 0,931226 & 3,037652 \\
\hline [842] Women's clothing, of textile fabrics & 0,487317 & 0,482147 & 0,724805 & 0,827708 & 1,114937 & 3,636914 \\
\hline [843] Men's or boy's clothing, of textile, knitted, croche. & 0,251887 & 0,249214 & 0,37464 & 0,427829 & 0,576293 & 1,879864 \\
\hline [844] Women's clothing, of textile, knitted or crocheted & 0,433948 & 0,429344 & 0,645427 & 0,737061 & 0,992833 & 3,238613 \\
\hline [845] Articles of apparel, of textile fabrics, n.e.s. & 0,897008 & 0,887492 & 1,334154 & 1,523569 & 2,052274 & 6,694497 \\
\hline [846] Clothing accessories, of textile fabrics & 0,023633 & 0,023383 & 0,035151 & 0,040141 & 0,054071 & 0,17638 \\
\hline [848] Articles of apparel, clothing access., excluding textile & 0,057635 & 0,057024 & 0,085723 & 0,097893 & 0,13186 & 0,43014 \\
\hline
\end{tabular}

Sumber : UN Comtrade (2016) diolah

\section{3) Adaptations}

\section{Adaptiveness Produk Ekspor TPT Indonesia ke RRT}

Produk ekspor TPT Indonesia yang memiliki kemampuan untuk beradaptasi dengan keinginan pasar di RRT adalah mempunyai hasil (A) positif dan dapat ditunjukkan pada Tabel 11, yaitu Cotton HS 263, Other Man Made Fibre Suitable for Spinning HS 267, Worn Clothing and other Worn Textile Articles HS 269, Knitted or Crocheted Fabrics HS 655,
Men's or Boy's Clothing HS 843, Clothing Accessories HS 846 dan Articles of Apparel HS 848. Sebaliknya hasil (A) negatif menunjukkan bahwa produk-produk tersebut tidak memiliki kemampuan untuk beradaptasi dengan selera pasar di RRT yaitu silk, Vegetable textile fibres, synthetic fibres, wool and other animal hair dan lain-lain. Dukungan pemerintah diperlukan agar produk-produk tersebut dapat diminati di pasar RRT. 
Tabel 11. Adaptation TPT Indonesia di RRT, 2011-2015

\begin{tabular}{|c|c|c|c|c|c|c|}
\hline Tekstil dan Produk Tekstil Indonesia & 2011 & 2012 & 2013 & 2014 & 2015 & A 5 th \\
\hline [261] Silk & 0,0000 & 0,0000 & 0,0000 & 0,0000 & 0,0000 & 0,0000 \\
\hline [263] Cotton & $8,44 \mathrm{E}-09$ & 4,37E-08 & $4,71 \mathrm{E}-08$ & $1,15 \mathrm{E}-08$ & $9,03 E-09$ & $1,2 \mathrm{E}-07$ \\
\hline [265] Vegetable textile fibres, not spun; waste of them & $1,44 \mathrm{E}-08$ & $3,65 \mathrm{E}-08$ & $-4,4 \mathrm{E}-08$ & $-1,12 \mathrm{E}-07$ & $8,05 \mathrm{E}-09$ & $-9,66 \mathrm{E}-08$ \\
\hline [266] Synthetic fibres suitable for spinning & $-7,02 \mathrm{E}-09$ & 2,84E-09 & $5,42 \mathrm{E}-09$ & $-1,91 \mathrm{E}-08$ & $-7,85 \mathrm{E}-09$ & $-2,57 \mathrm{E}-08$ \\
\hline [267] Other man-made fibres suitable for spinning & $1,39 \mathrm{E}-07$ & $4,61 \mathrm{E}-07$ & $-8,74 \mathrm{E}-08$ & $7,75 \mathrm{E}-08$ & $1,53 \mathrm{E}-07$ & $7,43 E-07$ \\
\hline [268] Wool and other animal hair (incl. wool tops) & 0,00000 & 0,00000 & 0,00000 & 0,00000 & 0,00000 & 0,00000 \\
\hline [269] Worn clothing and other worn textile articles & $3,78 \mathrm{E}-08$ & 7,31E-08 & $-2,36 \mathrm{E}-08$ & $-3,83 E-08$ & $-7,08 E-09$ & $4,19 \mathrm{E}-08$ \\
\hline [651] Textile yarn & $-6,02 \mathrm{E}-07$ & $-1,8 \mathrm{E}-06$ & $4,59 \mathrm{E}-07$ & $-2,19 E-06$ & $5,98 \mathrm{E}-07$ & $-3,54 \mathrm{E}-06$ \\
\hline [652] Cotton fabrics, woven & $-4,4 \mathrm{E}-08$ & $8,14 \mathrm{E}-08$ & 9,35E-09 & $-6,67 \mathrm{E}-08$ & $4,24 \mathrm{E}-10$ & $-1,95 \mathrm{E}-08$ \\
\hline [653] Fabrics, woven, of man-made fabrics & $-4,2 \mathrm{E}-08$ & $-1,02 \mathrm{E}-09$ & $-8,49 E-09$ & $-6,02 \mathrm{E}-08$ & $3,55 \mathrm{E}-08$ & $-7,63 E-08$ \\
\hline [654] Other textile fabrics, woven & $-4,48 \mathrm{E}-10$ & $-1,1 \mathrm{E}-09$ & $4,31 \mathrm{E}-10$ & $-7,3 \mathrm{E}-10$ & $3,51 \mathrm{E}-10$ & $-1,5 \mathrm{E}-09$ \\
\hline [655] Knitted or crocheted fabrics, n.e.s. & $-4,48 \mathrm{E}-08$ & 1,09E-07 & 1,54E-09 & $3,34 \mathrm{E}-08$ & 1,11E-08 & $1,11 \mathrm{E}-07$ \\
\hline [656] Tulles, trimmings, lace, ribbons \& other small ware & $-2,56 \mathrm{E}-09$ & $-2,09 \mathrm{E}-09$ & 9,71E-09 & $-6,13 E-09$ & $-1,6 \mathrm{E}-09$ & $-2,67 \mathrm{E}-09$ \\
\hline [657] Special yarn, special textile fabrics \& related & $-5,19 E-08$ & $-2,35 \mathrm{E}-07$ & $4,03 E-08$ & $1,35 \mathrm{E}-07$ & $1,36 \mathrm{E}-08$ & $-9,79 \mathrm{E}-08$ \\
\hline [658] Made-up articles, of textile materials, n.e.s. & $-1,5 \mathrm{E}-08$ & $-8,3 E-08$ & $-7,04 \mathrm{E}-09$ & $-1,78 \mathrm{E}-09$ & $-3,16 \mathrm{E}-08$ & $-1,38 \mathrm{E}-07$ \\
\hline [831] Travel goods, handbags \& similar containers & $-7,46 \mathrm{E}-09$ & $-1,01 \mathrm{E}-07$ & $-5,41 \mathrm{E}-09$ & $-7,81 \mathrm{E}-08$ & 2,7E-08 & $-1,65 \mathrm{E}-07$ \\
\hline [841] Men's clothing of textile fabrics, not knitted & $4,15 \mathrm{E}-08$ & $-1,09 \mathrm{E}-07$ & 4,57E-08 & $-3,6 \mathrm{E}-07$ & $1,3 \mathrm{E}-07$ & $-2,52 \mathrm{E}-07$ \\
\hline [842] Women's clothing, of textile fabrics & 5,97E-09 & $-1,86 \mathrm{E}-07$ & $6,12 \mathrm{E}-08$ & $-2,7 \mathrm{E}-07$ & $1,49 \mathrm{E}-07$ & $-2,39 \mathrm{E}-07$ \\
\hline [843] Men's or boy's clothing, of textile, knitted, croche. & $1,22 \mathrm{E}-08$ & $-1,99 \mathrm{E}-08$ & $2,22 \mathrm{E}-08$ & $-5,67 E-08$ & $5,69 E-08$ & 1,47E-08 \\
\hline [844] Women's clothing, of textile, knitted or crocheted & 2,04E-08 & $-5,99 \mathrm{E}-08$ & $4,9 \mathrm{E}-08$ & $-1,25 \mathrm{E}-07$ & 7,07E-08 & $-4,44 \mathrm{E}-08$ \\
\hline [845] Articles of apparel, of textile fabrics, n.e.s. & $5,46 \mathrm{E}-08$ & $-3,65 E-07$ & $5,82 \mathrm{E}-08$ & $-4,28 \mathrm{E}-07$ & $2,76 \mathrm{E}-07$ & $-4,04 \mathrm{E}-07$ \\
\hline [846] Clothing accessories, of textile fabrics & 4,68E-09 & $7,62 \mathrm{E}-09$ & $4,06 \mathrm{E}-11$ & $-1,14 \mathrm{E}-08$ & $8,78 \mathrm{E}-09$ & $9,71 \mathrm{E}-09$ \\
\hline [848] Articles of apparel, clothing access. & $-1,55 \mathrm{E}-08$ & $1,22 \mathrm{E}-08$ & $-2,32 \mathrm{E}-09$ & $-1,61 \mathrm{E}-08$ & $2,41 \mathrm{E}-08$ & 2,33E-09 \\
\hline
\end{tabular}

Sumber : UN Comtrade (2016) diolah

\section{Adaptiveness Produk Ekspor TPT Vietnam ke RRT}

Produk ekspor TPT Vietnam yang memiliki kemampuan untuk beradaptasi dengan selera pasar di RRT adalah ditunjukkan pada Tabel
12, antara lain jenis barang Cotton $\mathrm{HS}$ 263, Other Textile Fabrics Woven HS 654, Knitted or Crocheted Fabrics HS 655, Floor Coverings HS 659, Clothing Accessories of Textiles Fabrics HS 846. 
Tabel 12. Adaptation TPT Vietnam di RRT, 2011-2015

\begin{tabular}{|c|c|c|c|c|c|c|}
\hline Tekstil dan Produk Tekstil Vietnam & 2011 & 2012 & 2013 & 2014 & 2015 & A 5 th \\
\hline [261] Silk & 0,00000 & 0,00000 & 0,00000 & $-7,69 \mathrm{E}-10$ & 1,14E-09 & 0,00000 \\
\hline [263] Cotton & $4,14 \mathrm{E}-09$ & $-5,32 \mathrm{E}-08$ & $-1,15 \mathrm{E}-08$ & $1,52 \mathrm{E}-08$ & 8,91E-08 & $4,38 \mathrm{E}-08$ \\
\hline [265] Vegetable textile fibres, not spun; waste of them & $-3,18 \mathrm{E}-08$ & $1,48 \mathrm{E}-08$ & $2,45 E-08$ & $5,6 \mathrm{E}-08$ & $-3,66 \mathrm{E}-07$ & $-3,02 \mathrm{E}-07$ \\
\hline [266] Synthetic fibres suitable for spinning & $-7,22 \mathrm{E}-09$ & $-4 \mathrm{E}-10$ & $5,69 \mathrm{E}-11$ & $5,85 \mathrm{E}-10$ & $-6,23 E-09$ & $-1,32 \mathrm{E}-08$ \\
\hline [267] Other man-made fibres suitable for spinning & $-8,78 \mathrm{E}-10$ & $-1,77 \mathrm{E}-08$ & $4,05 \mathrm{E}-09$ & 0,0000 & 0,0000 & 0,0000 \\
\hline [268] Wool and other animal hair (incl. wool tops) & 0,00000 & 0,00000 & 0,00000 & 0,0000 & 0,0000 & 0,0000 \\
\hline [269] Worn clothing and other worn textile articles & $5,39 E-08$ & $-1,23 \mathrm{E}-07$ & $2,75 \mathrm{E}-08$ & 2,92E-08 & $-1,33 \mathrm{E}-07$ & $-1,45 \mathrm{E}-07$ \\
\hline [651] Textile yarn & $-1,07 \mathrm{E}-07$ & $-1,3 \mathrm{E}-06$ & $-9,72 \mathrm{E}-07$ & $1,34 \mathrm{E}-06$ & $-6,48 \mathrm{E}-06$ & $-7,52 \mathrm{E}-06$ \\
\hline [652] Cotton fabrics, woven & $-2,44 \mathrm{E}-09$ & $-4,71 \mathrm{E}-10$ & $-3,98 \mathrm{E}-09$ & $-2,88 \mathrm{E}-09$ & $3,99 \mathrm{E}-08$ & $3,02 \mathrm{E}-08$ \\
\hline [653] Fabrics, woven, of man-made fabrics & $-2,72 \mathrm{E}-08$ & $6,22 \mathrm{E}-08$ & $1,35 \mathrm{E}-09$ & $-3,88 E-09$ & $-2,22 \mathrm{E}-07$ & $-1,9 \mathrm{E}-07$ \\
\hline [654] Other textile fabrics, woven & $-1,65 \mathrm{E}-09$ & $3,7 \mathrm{E}-10$ & $2,97 \mathrm{E}-10$ & $-1,21 \mathrm{E}-10$ & $2,14 \mathrm{E}-09$ & $1,04 \mathrm{E}-09$ \\
\hline [655] Knitted or crocheted fabrics, n.e.s. & $2,15 \mathrm{E}-08$ & $5,54 \mathrm{E}-08$ & $-7,72 \mathrm{E}-09$ & 2,3E-09 & $5,06 \mathrm{E}-07$ & $5,78 \mathrm{E}-07$ \\
\hline [656] Tulles, trimmings, lace, ribbons \& other & $-5,93 E-10$ & $-1,41 \mathrm{E}-08$ & $-6,23 \mathrm{E}-10$ & 1,95E-09 & $-4,03 E-08$ & $-5,36 \mathrm{E}-08$ \\
\hline [657] Special yarn, special textile fabrics \& related & $2,43 E-10$ & $6,35 \mathrm{E}-08$ & $-1,91 E-08$ & $3,81 \mathrm{E}-08$ & $-3,93 E-07$ & $-3,1 \mathrm{E}-07$ \\
\hline [658] Made-up articles, of textile materials, n.e.s. & $5 \mathrm{E}-09$ & $3,12 \mathrm{E}-09$ & $-2,05 \mathrm{E}-08$ & $-2,97 \mathrm{E}-09$ & $-2,25 \mathrm{E}-08$ & $-3,79 E-08$ \\
\hline [659] Floor coverings, etc. & $5,71 \mathrm{E}-11$ & $6,29 \mathrm{E}-10$ & $-5,81 \mathrm{E}-11$ & $-4,23 E-11$ & $-4,34 \mathrm{E}-11$ & $5,42 \mathrm{E}-10$ \\
\hline [841] Men's clothing of textile fabrics, not knitted & $1,08 \mathrm{E}-07$ & 3,91E-08 & $-1,07 \mathrm{E}-07$ & 9,93E-08 & $-3,9 \mathrm{E}-07$ & $-2,51 \mathrm{E}-07$ \\
\hline [842] Women's clothing, of textile fabrics & $9,37 \mathrm{E}-08$ & $-1,23 E-07$ & $-1,45 \mathrm{E}-07$ & $6,9 \mathrm{E}-10$ & $-1,37 \mathrm{E}-07$ & $-3,1 \mathrm{E}-07$ \\
\hline [843] Men's or boy's clothing, of textile, knitted, croche. & $3,06 \mathrm{E}-09$ & $-6,83 E-08$ & $-4,91 \mathrm{E}-08$ & $2,23 E-08$ & $5,26 \mathrm{E}-08$ & $-3,94 \mathrm{E}-08$ \\
\hline [844] Women's clothing, of textile, knitted or crocheted & $4,16 \mathrm{E}-08$ & $-4,83 E-08$ & $-4,96 \mathrm{E}-08$ & $1,02 \mathrm{E}-07$ & $-1,77 \mathrm{E}-07$ & $-1,31 \mathrm{E}-07$ \\
\hline [845] Articles of apparel, of textile fabrics, n.e.s. & $1,1 \mathrm{E}-07$ & $-2,23 \mathrm{E}-07$ & $-2,33 \mathrm{E}-07$ & 2,07E-07 & $-2,74 \mathrm{E}-07$ & $-4,12 \mathrm{E}-07$ \\
\hline [846] Clothing accessories, of textile fabrics & $6,7 \mathrm{E}-10$ & $-8,62 \mathrm{E}-10$ & $-2,65 \mathrm{E}-09$ & $1,28 \mathrm{E}-08$ & $-2,54 \mathrm{E}-09$ & $7,42 \mathrm{E}-09$ \\
\hline [848] Articles of apparel, clothing access. & $8,42 \mathrm{E}-09$ & $-5,94 \mathrm{E}-08$ & $2,14 \mathrm{E}-10$ & $-1,15 \mathrm{E}-08$ & $-1,18 \mathrm{E}-08$ & $-7,4 \mathrm{E}-08$ \\
\hline
\end{tabular}

Sumber : UN Comtrade (2016) diolah

Dari hasil (A) TPT dua negara ke pasar RRT, baik Indonesia dan Vietnam sama-sama mempunyai beberapa jenis produk ekspor TPT yang mempunyai kemampuan untuk dapat beradaptasi dengan keinginan dan selera atau situasi pasar di RRT.

\section{Adaptiveness Produk Ekspor TPT Indonesia ke Amerika Serikat}

Produk ekspor TPT Indonesia yang memiliki kemampuan untuk beradaptasi dengan keinginan pasar di Amerika Serikat antara lain adalah Cotton HS
263, Synthetic Fibres Suitable for Spinning HS 266, Other Man Made Fibres Suitable for Spinning HS 267, Knitted or Crocheted Fabrics HS 655, Special Yam, Special Textile Fabrics and Related HS 657 dan Floor Covering HS 659 (Tabel 13). Sebaliknya produk tidak memiliki kemampuan untuk beradaptasi di pasar Amerika Serikat antara lain adalah silk, Vegetable Textile Fibres, Synthetic Fibres, Wool and Other Animal Hair, Textile Yarn dan lain-lain. 
Tabel 13. Adaptation TPT Indonesia di Amerika Serikat, 2011-2015

\begin{tabular}{|c|c|c|c|c|c|c|}
\hline Tekstil dan Produk Tekstil & 2011 & 2012 & 2013 & 2014 & 2015 & A 5 th \\
\hline [261] Silk & 0,00000 & 0,00000 & 0,00000 & 0,00000 & 0,00000 & 0,00000 \\
\hline [263] Cotton & $5,17 \mathrm{E}-09$ & $2,28 \mathrm{E}-08$ & $-6,3 \mathrm{E}-09$ & $-1,3 \mathrm{E}-11$ & $\begin{array}{c}\text { 1,57E-09 } \\
-3,34 \mathrm{E}-\end{array}$ & 2,33E-08 \\
\hline [265] Vegetable textile fibres, not spun; waste of them & $-7,6 \mathrm{E}-11$ & $-3,2 \mathrm{E}-10$ & $-2,3 \mathrm{E}-10$ & $-4,2 \mathrm{E}-15$ & 11 & $-6,6 \mathrm{E}-10$ \\
\hline [266] Synthetic fibres suitable for spinning & $4,05 \mathrm{E}-08$ & $1,66 \mathrm{E}-08$ & $-2,6 \mathrm{E}-08$ & $1,29 \mathrm{E}-10$ & 9,55E-09 & $4,04 \mathrm{E}-08$ \\
\hline [267] Other man-made fibres suitable for spinning & $-4,1 \mathrm{E}-08$ & $9,56 \mathrm{E}-08$ & $-5,4 \mathrm{E}-08$ & $1,2 \mathrm{E}-10$ & $2,45 \mathrm{E}-08$ & 2,43E-08 \\
\hline [268] Wool and other animal hair (incl. wool tops) & 0,00000 & 0,00000 & 0,00000 & 0,00000 & $5,47 \mathrm{E}-11$ & 0,0000 \\
\hline [269] Worn clothing and other worn textile articles & $5,14 \mathrm{E}-12$ & $-4,6 \mathrm{E}-12$ & 0,00000 & 0,00000 & $-6,4 \mathrm{E}-11$ & 0,0000 \\
\hline [651] Textile yarn & 9,68E-09 & $-7,8 \mathrm{E}-08$ & $-7,1 \mathrm{E}-08$ & $8,88 \mathrm{E}-10$ & $-4,7 \mathrm{E}-08$ & $-1,9 \mathrm{E}-07$ \\
\hline [652] Cotton fabrics, woven & $-5,7 \mathrm{E}-09$ & $-4,5 \mathrm{E}-08$ & $-2,3 \mathrm{E}-08$ & $2,45 \mathrm{E}-10$ & $-1,2 \mathrm{E}-08$ & $-8,6 \mathrm{E}-08$ \\
\hline [653] Fabrics, woven, of man-made fabrics & $1,16 \mathrm{E}-08$ & 1,71E-09 & $-1,1 \mathrm{E}-08$ & $3,53 \mathrm{E}-11$ & $-9,4 \mathrm{E}-09$ & $-7,3 \mathrm{E}-09$ \\
\hline [654] Other textile fabrics, woven & $-2,3 E-10$ & $-3,9 \mathrm{E}-09$ & $-2,8 \mathrm{E}-09$ & $-2,5 \mathrm{E}-11$ & 1,18E-09 & $-5,7 \mathrm{E}-09$ \\
\hline [655] Knitted or crocheted fabrics, n.e.s. & 2,73E-08 & $-6,1 \mathrm{E}-10$ & $-1,4 \mathrm{E}-08$ & $2,98 \mathrm{E}-11$ & $-9,8 E-10$ & 1,19E-08 \\
\hline [656] Tulles, trimmings, lace, ribbons \& other & $-2,8 \mathrm{E}-11$ & $-2,2 \mathrm{E}-08$ & 4,99E-10 & $1,21 \mathrm{E}-11$ & $5,76 \mathrm{E}-09$ & $-1,6 \mathrm{E}-08$ \\
\hline [657] Special yarn, special textile fabrics \& related & $8,26 \mathrm{E}-09$ & $8,88 \mathrm{E}-09$ & $1,44 \mathrm{E}-08$ & $-2 \mathrm{E}-10$ & $-6,6 \mathrm{E}-09$ & 2,47E-08 \\
\hline [658] Made-up articles, of textile materials, n.e.s. & $-8,2 \mathrm{E}-08$ & 1,7E-08 & $2,06 \mathrm{E}-08$ & $1,05 \mathrm{E}-10$ & $-2,5 \mathrm{E}-09$ & $-4,7 \mathrm{E}-08$ \\
\hline [659] Floor coverings, etc. & 1,06E-08 & $1,89 \mathrm{E}-08$ & 6,7E-09 & $1,73 \mathrm{E}-10$ & $-4,2 \mathrm{E}-10$ & $3,59 \mathrm{E}-08$ \\
\hline [841] Men's clothing of textile fabrics, not knitted & $-1,6 \mathrm{E}-07$ & $-4,3 \mathrm{E}-07$ & $-2,1 \mathrm{E}-08$ & 1,59E-09 & $-3,2 \mathrm{E}-07$ & $-9,3 \mathrm{E}-07$ \\
\hline [842] Women's clothing, of textile fabrics & 1,94E-07 & $-8,5 \mathrm{E}-07$ & 4,41E-07 & $5,73 E-09$ & $-4,5 \mathrm{E}-07$ & $-6,6 \mathrm{E}-07$ \\
\hline [843] Men's or boy's clothing, of textile, knitted, croche. & 1,61E-07 & $-6,2 \mathrm{E}-07$ & $-1,1 \mathrm{E}-07$ & 2,82E-09 & $-1,4 \mathrm{E}-08$ & $-5,9 \mathrm{E}-07$ \\
\hline [844] Women's clothing, of textile, knitted or crocheted & $4,73 \mathrm{E}-08$ & $-1,1 \mathrm{E}-06$ & $-3,9 E-07$ & $-3,1 \mathrm{E}-10$ & $-7,4 \mathrm{E}-08$ & $-1,5 \mathrm{E}-06$ \\
\hline [845] Articles of apparel, of textile fabrics, n.e.s. & $3,28 \mathrm{E}-07$ & $-2,4 \mathrm{E}-06$ & $-2 \mathrm{E}-06$ & $5,72 \mathrm{E}-09$ & $-5,7 \mathrm{E}-07$ & $-4,6 \mathrm{E}-06$ \\
\hline [846] Clothing accessories, of textile fabrics & $3,16 \mathrm{E}-08$ & $-9,2 \mathrm{E}-08$ & $-2,6 \mathrm{E}-08$ & $-4,7 \mathrm{E}-10$ & $-3,5 \mathrm{E}-08$ & $-1,2 \mathrm{E}-07$ \\
\hline [848] Articles of apparel, clothing access. & 6,34E-08 & $-1,1 \mathrm{E}-07$ & $-1,2 \mathrm{E}-07$ & $3,57 \mathrm{E}-10$ & $-1,1 \mathrm{E}-07$ & $-2,8 \mathrm{E}-07$ \\
\hline
\end{tabular}

Sumber : UN Comtrade (2016) diolah

\section{Adaptiveness Produk Ekspor TPT Vietnam ke Amerika Serikat}

Hasil (A) untuk jenis-jenis produk ekspor TPT Vietnam lebih dominan negatif yang berarti memiliki kesulitan untuk beradaptasi dengan keinginan/ selera pasar di Amerika Serikat. Namun ada beberapa jenis barang selama lima tahun mempunyai rata-rata masih relatif baik untuk beradaptasi dengan keinginan dan selera pasar di Amerika Serikat seperti Cotton, Synthetic Fibres, Other Man-Made Fibres, Knitted of Crocheted Fabrics, Special Yarn dan Floor Coverings (Tabel 14). 
Tabel 14. Adaptation TPT Vietnam di Amerika Serikat, 2011-2015

\begin{tabular}{|c|c|c|c|c|c|c|}
\hline Tekstil dan Produk Tekstil & 2011 & 2012 & 2013 & 2014 & 2015 & A 5 th \\
\hline [261] Silk & 0,00000 & 0,00000 & 0,00000 & 0,00000 & 0,00000 & 0,00000 \\
\hline [263] Cotton & 0,00000 & 0,00000 & 0,00000 & 0,00000 & 0,00000 & 0,00000 \\
\hline [265] Vegetable textile fibres, not spun; waste of them & $-1,4 \mathrm{E}-05$ & 1,7E-06 & $6,46 \mathrm{E}-06$ & $5,67 \mathrm{E}-06$ & $-2,9 \mathrm{E}-06$ & $-3,4 \mathrm{E}-06$ \\
\hline [266] Synthetic fibres suitable for spinning & $-0,00078$ & 2,51E-05 & $-0,00055$ & 0,000517 & $-0,00051$ & $-0,0013$ \\
\hline [267] Other man-made fibres suitable for spinning & 0,00000 & 0,00000 & 0,00000 & $-6,5 \mathrm{E}-08$ & 0,00000 & 0,00000 \\
\hline [268] Wool and other animal hair (incl. wool tops) & 0,00000 & 0,00000 & 0,00000 & 0,00000 & 0,00000 & 0,00000 \\
\hline [269] Worn clothing and other worn textile articles & $-2,5 \mathrm{E}-06$ & 2,89E-07 & $-4,6 \mathrm{E}-07$ & $9,16 \mathrm{E}-07$ & $8,74 \mathrm{E}-07$ & $-8,5 \mathrm{E}-07$ \\
\hline [651] Textile yarn & $-0,00147$ & $7,05 E-05$ & 0,000269 & 0,000338 & $-0,00147$ & $-0,00227$ \\
\hline [652] Cotton fabrics, woven & $-1,5 \mathrm{E}-05$ & 7,11E-07 & $2,62 \mathrm{E}-07$ & 1,98E-06 & $-1 \mathrm{E}-05$ & $-2,2 \mathrm{E}-05$ \\
\hline [653] Fabrics, woven, of man-made fabrics & $-0,00089$ & 3,01E-05 & $7,68 \mathrm{E}-05$ & 0,000453 & $-0,00087$ & $-0,00119$ \\
\hline [654] Other textile fabrics, woven & $-2,3 \mathrm{E}-05$ & $1,24 \mathrm{E}-06$ & $-9,3 E-06$ & 2,71E-06 & $-9,8 \mathrm{E}-07$ & $-2,9 \mathrm{E}-05$ \\
\hline [655] Knitted or crocheted fabrics, n.e.s. & $-0,00035$ & $1,35 \mathrm{E}-05$ & $-0,00017$ & 0,000142 & $-0,00024$ & $-0,0006$ \\
\hline [656] Tulles, trimmings, lace, ribbons \& other & $-0,00017$ & $5,85 E-06$ & $-1,3 E-06$ & 0,00014 & $-0,00017$ & $-0,0002$ \\
\hline [657] Special yarn, special textile fabrics \& related & $-0,01547$ & 0,000642 & $-0,00038$ & 0,004913 & $-0,01191$ & $-0,02221$ \\
\hline [658] Made-up articles, of textile materials, n.e.s. & $-0,00603$ & 0,00025 & $-0,00058$ & 0,002581 & $-0,00506$ & $-0,00883$ \\
\hline [659] Floor coverings, etc. & $-2,4 \mathrm{E}-06$ & $6,09 \mathrm{E}-07$ & 5,89E-06 & $2,5 \mathrm{E}-05$ & $-6,6 \mathrm{E}-05$ & $-3,6 \mathrm{E}-05$ \\
\hline [841] Men's clothing of textile fabrics, not knitted & $-0,07057$ & 0,002917 & $-0,00184$ & 0,034198 & $-0,06494$ & $-0,10024$ \\
\hline [842] Women's clothing, of textile fabrics & $-0,08016$ & 0,003323 & $-0,00262$ & 0,037412 & $-0,07268$ & $-0,11472$ \\
\hline [843] Men's or boy's clothing, of textile, knitted, croche. & $-0,0449$ & 0,001701 & 0,000845 & 0,024593 & $-0,04223$ & $-0,05999$ \\
\hline [844] Women's clothing, of textile, knitted or crocheted & $-0,07258$ & 0,002794 & $-0,00438$ & 0,043352 & $-0,08144$ & $-0,11225$ \\
\hline [845] Articles of apparel, of textile fabrics, n.e.s. & $-0,15177$ & 0,006252 & $-0,01113$ & 0,072986 & $-0,13005$ & $-0,21371$ \\
\hline [846] Clothing accessories, of textile fabrics & $-0,00431$ & 0,00015 & $-0,00017$ & 0,0029 & $-0,00482$ & $-0,00625$ \\
\hline [848] Articles of apparel, clothing access. & $-0,00993$ & 0,000413 & $-0,00098$ & 0,004455 & $-0,00737$ & $-0,01341$ \\
\hline
\end{tabular}

Sumber : UN Comtrade (2016) diolah

Kedua negara mempunyai kemampuan untuk beradaptasi memasuki pasar ekspor jenis barang TPT di pasaran RRT namun produk TPT Vietnam relatif tidak mempunyai jenis barang TPT yang dapat beradaptasi di pasar Amerika Serikat.

\section{Determinan Kinerja Ekspor TPT Indonesia dan Vietnam}

Hasil penelitian ini yang menggunakan regresi dengan lima model untuk menggambarkan bahwa hubungan antara variabel-variabel independen (nilai tukar riil, tarif, GDP negara tujuan, dan FDI sektor manufaktur negara asal) mayoritas sesuai teori meskipun hanya ditemukan di model-model tertentu. Hanya satu temuan dimana tarif produk manufaktur di Amerika Serikat dan RRT ternyata berbanding lurus dengan ekspor TPT Vietnam ke kedua negara tersebut. Hal ini dapat disebabkan oleh keterbatasan data tarif yang merupakan rerata tertimbang untuk seluruh produk manufaktur, bukan TPT secara spesifik. 
Tabel 15. Hasil Model Determinasi Daya Saing TPT Indonesia dan Vietnam ke AS dan RRT

\begin{tabular}{cccccc}
\hline Model & $\begin{array}{c}\text { Menurut Asal } \\
\text { Negara dan } \\
\text { Pasar Ekspor }\end{array}$ & $\begin{array}{c}\text { Menurut Asal Negara } \\
\text { Ekspor }\end{array}$ & \multicolumn{2}{c}{$\begin{array}{c}\text { Menurut Pasar Tujuan } \\
\text { Ekspor }\end{array}$} \\
\cline { 2 - 6 } Variabel & Model 1 & Model 2 & Model 3 & Model 4 & Model 5 \\
\hline In_rer & 0.416 & -0.092 & $3.414^{* * *}$ & 0.512 & -0.505 \\
& $(0.561)$ & $(0.175)$ & $(1.225)$ & $(0.829)$ & $(0.527)$ \\
tariff & -0.003 & 0.045 & $0.296^{* * *}$ & $-1.886^{* *}$ & -0.032 \\
& $(0.068)$ & $(0.028)$ & $(0.065)$ & $(0.881)$ & $(0.403)$ \\
In_gdp & 0.732 & $1.652^{* * *}$ & $3.123^{* * *}$ & -2.325 & 0.718 \\
& $(0.720)$ & $(0.274)$ & $(0.350)$ & $(3.635)$ & $(0.575)$ \\
In_fdi & $1.549^{* * *}$ & 0.057 & $2.116^{* * *}$ & $1.534^{\star * *}$ & $1.046^{* * *}$ \\
Observasi & $(0.181)$ & $(0.889)$ & $(0.225)$ & $(0.302)$ & $(0.218)$ \\
$\mathrm{R}^{2}$ & 88 & 44 & 44 & 44 & 44 \\
\hline
\end{tabular}

Keterangan:

- Model 1 adalah keseluruhan INA ke USA, INA ke RRT, VIE ke USA, VIE ke RRT;

- Model 2 adalah INA ke USA dan INA ke RRT;

- Model 3 adalah VIE ke USA dan VIE ke RRT;

- Model 4 adalah INA ke USA dan VIE ke USA;

- Model 5 adalah INA ke RRT dan VIE ke RRT.

Dari hasil regresi dengan lima model yang kemudian memilah menjadi 3, dimaksudkan untuk melihat variasi hasil regresi di lihat dari kesesuaian dengan teori yang menyatakan bahwa daya saing dipengaruhi oleh nilai tukar riil, tarif yang berlaku, GDP negara tujuan dan FDI sektor manufaktur negara asal, maka dapat dijelaskan sebagai berikut:

Model menurut asal negara dan pasar tujuan ekspor (model 1), yang mengggunakan keseluruhan data hubungan dagang Indonesia ke AS, Indonesia ke RRT, Vietnam ke AS dan Vietnam ke RRT, didapat bahwa daya saing (RCA) TPT dipengaruhi secara signifikan oleh FDI di sektor manufaktur di negara asal dibanding dengan faktor lain baik nilai tukar riil, tarif dan GDP negara tujuan.

Model menurut negara asal ekspor (model 2 dan 3), yang menggunakan data hubungan dagang Indonesia ke AS dan Indonesia ke RRT, serta data hubungan dagang Vietnam ke AS dan 
Vietnam ke RRT didapat bahwa daya saing ekspor TPT untuk Indonesia sangat dipengaruhi faktor GDP negara tujuan sedangkan Vietnam sangat dipengaruhi oleh faktor nilai tukar riil, tarif, GDP negara tujuan dan FDI di sektor manufaktur Vietnam.

\section{Model menurut negara pasar tujuan} ekspor (model 4 dan 5) yang menggunakan keseluruhan data hubungan Indonesia ke AS dan Vietnam ke AS serta data hubungan dagang Indonesia ke RRT dan hubungan dagang Vietnam ke RRT, didapat hasil bahwa untuk pasar AS dipengaruhi signifikan secara negatif oleh tarif serta positif oleh faktor FDI dan GDP negara tujuan serta secara positif oleh faktor FDI sektor manufaktur negara asal. Sedangkan untuk tujuan pasar ekspor RRT sangat dipengaruhi oleh faktor FDI sektor manufaktur negara asal.

\section{KESIMPULAN DAN REKOMENDASI KEBIJAKAN}

Daya saing TPT Indonesia saat ini masih relatif kuat. Hasil RCA selama lima tahun (2010-2015) menunjukkan bahwa nilai RCA beberapa item TPT Indonesia masih lebih besar dari 1 . Dari hasil CMSA, menunjukkan bahwa daya saing produk TPT kedua negara masih relatif lemah di pasar ekspor
RRT. Sedangkan daya saing TPT kedua negara di pasar ekspor AS relatif kuat untuk beberapa jenis produk TPT.

Secara spesifik, beberapa jenis TPT Indonesia mempunyai daya saing kuat dibanding Vietnam. Untuk pengembangan produk TPT ternyata lebih banyak dilakukan Vietnam ke pasar ekspor RRT sedangkan Indonesia masih relatif kecil. Untuk pengembangan produk TPT ke pasar ekspor AS banyak dikuasai oleh jenis produk TPT Indonesia, sedangkan Vietnam hanya mempunyai beberapa jenis produk TPT saja. Jenis produk TPT Indonesia dan Vietnam ternyata mempunyai kemampuan untuk beradaptasi di pasar ekspor RRT. Namun, Vietnam tidak mempunyai jenis TPT yang dapat beradaptasi di pasar ekspor AS.

Untuk itu perlu dikembangkan beberapa jenis TPT Indonesia yang mampu beradaptasi dengan keinginan dan selera pasar RRT antara lain Cotton, Other Man-Made Fibres Suitable for Spinning, Worn Clothing and Other Worn Textile Articles, Knitted or Crocheted Fabrics, Men's or Boy's Clothing of Textile, Knitted, Croche, dan Articles of Apparel Clothing Access. Sedangkan jenis produk TPT yang perlu dikembangkan agar mampu 
beradaptasi dengan keinginan pasar di AS antara lain Cotton, Synthetic Fibres Suitable for Spinning, Other Man-Made Fibres Suitable for Spinning, Other Man-Made Fibres Suitable for Spinning, Knitted or Crocheted Fabrics,Special Yarn, Special Textile Fabrics dan Floor Coverings.

Hasil determinasi daya saing ekspor TPT asal Indonesia dan Vietnam ke pasar tujuan ekspor AS dan RRT sangat dipengaruhi oleh FDI sektor manufaktur negara asal. Menurut negara asal ekspor, determinasi daya saing ekspor TPT Indonesia sangat dipengaruhi faktor GDP negara tujuan sedangkan Vietnam sangat dipengaruhi oleh faktor nilai tukar riil, tarif, GDP negara tujuan dan FDI sektor manufaktur negara asal. Menurut daya saing negara pasar tujuan ekspor, determinasi daya saing ekspor TPT pasar AS dipengaruhi secara negatif oleh faktor tarif dan GDP negara tujuan serta secara positif oleh faktor FDI sektor manufaktur negara asal. Sedangkan untuk tujuan pasar ekspor RRT sangat dipengaruhi oleh faktor FDI sektor manufaktur negara asal.

Daya saing ekspor TPT Indonesia perlu ditingkatkan dengan senantiasa mencermati perkembangan dan dinamika FDI sektor manufaktur negara asal serta GDP negara tujuan. Demikian juga senantiasa mencermati negara tujuan ekspor AS berupa faktor tarif, GDP negara tujuan dan FDI sektor manufaktur negara asal. Sedangkan negara tujuan ekspor RRT berupa FDI sektor manufaktur negara asal.

\section{UCAPAN TERIMA KASIH}

Pada kesempatan ini penulis mengucapkan terima kasih kepada reviewer yang telah memberikan saran dan perbaikan demi kesempurnaan artikel ini. Demikian juga ucapan terima kasih penulis ucapkan kepada Kepala Pusat Kebijakan Regional dan Bilateral Badan Kebijakan Fiskal Kementerian Keuangan yang telah memberikan motivasi kepada penulis. Tidak lupa, disampaikan ucapan terima kasih kepada Saudara Ahmad Fikri Aulia staf Pusat Kebijakan Ekonomi Makro Badan Kebijakan Fiskal serta rekan rekan yang telah membantu dalam penyusunan artikel ini.

\section{DAFTAR PUSTAKA}

Ashari, P. Pandu. (2015). Analisis Daya Saing Ekspor Kopi Indonesia dan Turunannya di Kawasan Amerika Eropa Asia dan Australia. Skripsi. Fakultas Ekonomi dan Manajemen Institut Pertanian Bogor

Balassa. (1989). Comparative Advantage, Trade Policy and Economic Development. New York: Harvester wheatsheaf. 
Basri, F. \& Munandar, H. (2010). Dasardasar Ekonomi Internasional: Pengenalan \& Aplikasi Metode Kuantitatif. Jakarta. Kencana. Prenada Media Grup

Erkan, B. \& Sarıçoban, K. (2014). Comparative Analysis of the Competitiveness in the Export of Science-Based Goods Regarding Turkey and the EU+13 Countries. International Journal of Business and Social Science", 5, 8(1), 117-130

Imawan, R. (2002). Peningkatan Daya saing: Pendekatan ParadigmatikPolitis. Jurnal IImu Sosial dan IImu Politik. Universitas Gajah Mada. Volume 6 Th. 1 Juli 2002.

Kemendag. (2015). Rencana Strategis Kementerian Perdagangan tahun 2015-2019

Kemenperin. (2015a). Revitalisasi Permesinan Industri TPT (http://www.kemenperin.go.id/artikel/2 0/Revitalisasi-Permesinan-IndustriTPT diunduh 26 Juni 2017 jam 14:54)

Kemenperin. (2015b). Tekstil Andalan Persaingan di ASEAN dalam Berita Industri Kementerian Perindustraian (http://www.kemenperin.go.id/artikel/6 072/Tekstil-Andalan-Persaingan-diASEAN diunduh 16 Maret 2017 jam 10:10)

Kurniadi S. Dedi, dkk. (2017). Strategi Pengembangan Usaha Produk Tekstil di PT Priangan Sentosa Tasikmalaya Jawa Barat. Jurnal Manajemen IKM. Institut Teknologi Pertanian Bogor. Vol. 12 No. 1. Februari 2017.

Lotfi, B. \& Karim, M. (2016). Dutch Disease and Changes of the Productive Structure in Moroccan Economy. An Analysis Using VECM, Advances in
Management \& Applied Economics, Vol. 6, no. 4, 2016, 25-44

Nurlatifah, H. (2011). Analisis Daya Saing Produk-produk Indonesia di Pasar China. Jurnal Al Azhar Indonesia Seri Pranata Sosial. Vol. 1, No. 1, Maret 2011

OTEXA. South Korea. (2015). Market Reports,Textiles, Apparel, Footwear, and Travel Goods, (http://web.ita .doc.gov/tacgi/overseasnew.nsf/count ry/ KoreaSouth). diunduh 17 Mei 2017 jam 14:56

Permatasari, K. U. I Gusti \& Rusatariyani, D. Surya. (2014). Analisis Daya Saing Ekspor Biji Kakao Indonesia di Kawasan ASEAN Periode 20032012, Jurnal Ekonomi Pembangunan Universitas Udayana, E- Jurnal EP Unud. 4 [7] : 855-872

Ragimun. (2010). Analisis Kinerja Industri TPT Indonesia, Jurnal Ekonomi Keuangan, Vol 14 no. 4, Badan Kebijakan Fiskal Kementerian Keuangan

Rosalina, A. (2013). Analisis Daya Saing Industri Tekstil dan Produk Tekstil (TPT) Propinsi Jawa Barat tahun 1981-2010. Skripsi. Departemen Ekonomi Fakultas Ekonomi dan Manajemen. Institut Pertanian Bogor

Tambunan, T. (2001). Perdagangan Internasional dan Neraca Pembayaran, Teori dan temuan Empiris, LP3ES, Jakarta

Tyszynski, H. (1951). World Trade in Manufactured Commodities, 18991950, The Manchester School 19, 272-304

United Nations, Statistics Division. (2016). Commodity Trade Statistics Database, ww.comtrade.un.org/db/. 
